\title{
男子尿路・性器悪性腫瘍患者に対する制癌剂・放射線療法の
}

\section{視床下部・下垂体・性腺系と副腎皮質機能に 及ぼす影響に関する研究}

\author{
岡山大学医学部泌尿器科学教室 光 畑 直 喜
(主任: 大森弘教授)
}

\section{STUDIES ON THE EFFECTS OF ANTICANCER COMBINATION CHEMOTHERAPY \\ AND RADIOTHERAPY ON HYPOTHALAMO-PITUITARY-GONADAL AXIS AND ADRENOCORTICAL FUNCTION IN MALE GENITOURINARY CANCER PATIENTS}

\author{
Naoki Mitsuhata \\ Department of Urology, Okayama University Medical School, Okayama \\ (Director: Prof. Hiroyuki Ohmori)
}

In order to investigate the effects of anticancer combination therapy and radiotherapy on hypothalamo-pituitary-gonadal axis or adrenocortical function in 65 male urological cancer patients, plasma basal levels of luteinizing hormone ( $\mathrm{LH})$, follicle stimulating hormone $(\mathrm{FSH})$, testosterone (T), adrenocorticotropic hormone (ACTH), cortisol (F), dehydroepiandrosterone (DHA), dehydroepiandrosteronesulfate (DHA-S) and prolactin (PRL) and LH-releasing hormone (LH-RH) test, clomiphene citrate test and rapid ACTH test were evaluated before and after therapy.

Damage to germinal epithelium was assessed by testicular biopsy or examination of sperm count in testicular tumor patients.

The results were as follows:

1) As to pre-treatment evaluation in patients with urothelial cancer, penile cancer or renal cell carcinoma, significant high plasma levels of LH, FSH associated with significant low plasma levels of T showed the influence of male senescence, but no specific effect of any primary malignancies. By contrast, significant increase in plasma FSH levels with significant decrease of plasma T levels and hypospermatogenesis revealed by testicular biopsy or sperm counting in testicular tumor patients before cancer therapy suggested that contralateral testicular dysfunction had been pre-existing. Pre-treatment DHA concentrations tended to be subnormal with contralateral gonadal dysfunction, suggesting the decline of testicular origin DHA levels in these patients.

2) FSH levels rose significantly after cancer therapy in testicular tumor patients and fall of sperm count or germinal cell damage revealed by testicular biopsy developed further. None of these patients has so far recovered pre-treatment FSH levels or pre-treatment spermatogenesis in a follow up periods of 12 months, whereas $\mathrm{LH}$ and $\mathrm{T}$ levels did not change throughout radiotherapy or combination chemotherapy.

3) Significantly high levels of FSH $(p<0.01)$ and mild rise in LH levels $(p<0.05)$ with unchanged T levels were demonstrated after combination chemotherapy including radiotherapy in patients with urothelial cancer, penile cancer or renal cell carcinoma, while plasma gonadotropins and $\mathrm{T}$ had no change in patients treated with radiotherapy alone. Declining FSH and LH levels to pre-treatment levels seemed to take place 12 months after cessation of cancer therapy.

4) Responses of plasma gonadotropins to $\mathrm{LH}-\mathrm{RH}$ or responses of gonadotropins and T to clomiphene citrate remained intact before and after cancer therapy. The effects of anticancer combination therapy and radiotherapy on hypothalamo-pituitary-gonadal axis seemed to be primary testicular failure, 
mainly showing seminiferous tubular damages by cytotoxic action of each therapeutic drugs or by scattered fractionated irradiation to the testis.

5) Plasma F, DHA and DHA-S and responses to synthetic ACTH showed insignificant damage throughout adjuvant chemotherapy or radiotherapy.

6) PRL levels in patients with urological cancer showed no significant change before and after anticancer therapy in the present study.

要旨：前立腺癌を除く65例の男子尿路性器悪性腫瘍患者を対象として血中 LH，FSH，Tを中心に ACTH, F, DHA, DHA-S を測定し，一部症例に LH-RH テスト, clomiphene citrate 負荷テスト, rapid ACTH テスト, 精液検査, 冝丸生検を行ない, 制癌剂の多剂併用療法及び放射線療法の視床下部・下垂 体・性腺系と副腎皮質機能に及洔す影響を検討した。治療前值の検討では，尿路上皮腫瘍，陰茎癌，腎 癌例に加齢による睪丸機能低下と一部症例にDHA-S の低下が認められたのに対し, 辠丸腫瘍例では有 意な FSH の上昇, Tの低下がみられており, 精子濃度, 睪丸生検を含めて健側睪丸の機能低下が示唆さ れた。これに関連して睪丸腫瘍例の DHA の低下傾向は辠丸性 DHA の低下によるものと推定される. 放 射線療法を含む制癌剂療法後尿路上皮腫瘍, 陰茎癌, 腎癌例では FSH $(\mathrm{p}<0.01), \mathrm{LH}(\mathrm{p}<0.05)$ の上 昇が認められ，また主に放射線療法を実施した睪丸腫瘍例では，FSH $(\mathrm{p}<0.01)$ のみ上昇した。しかし 放射線単独療法を行なつた腎癌例では全くFSH，LHに变化が認められなかつた。血中Tに関しては治 療中, 治療後も有意な变動はなかつた。対射線療法を含む制癌剤療法では少なくとも視床下部, 下垂体 の障害は認められず, 個々の制癌剤の cytotoxic action と scattered fractionated irradiation による精 細管障害を主体とする原発性責丸機能低下を惹起すると推察される。またこれらの治療前後の副腎皮質 機能は影響を受けないと考吕られた。 PRLについても同様に治療により有意の差は認められなかつた。

\section{緒言}

近年尿路性器悪性腫瘍に対する化学療法, 特に多剂 併用療法及び放射線療法は積極的に実施される傾向に あるが，生体に及ぼす障害については，骨髄・肝・腎・ 肺・消化器等においてかなり検討されているものの, 視床下部，下垂体・殬丸機能及び副腎皮質機能に対す る影響については殆んど報告されていないのが現状で ある。本研究では，除悬術・ホルモン療法が主体を占 める前立腺癌を除く男子尿路性器悪性腫瘍患者に拈け る制癌剂，放射線療法前後の内分泌動態を検討するた めに, 血 中 luteinizing hormone (LH), follicle stimulating hormone (FSH), testosterone (T) 值を 中心として adrenocorticotropic hormone (ACTH), cortisol (F), dehydroepiandrosterone (DHA), dehydroepiandrosterone sulfate (DHA-S), prolactin （PRL)を測定し，一部症例に LH-RH テスト，clomiphene テスト, rapid ACTH テストを行つた.

また辠丸腫瘍患者を中心に治療前後の精液検査及び 辠丸生検を実施し，上記各種ホルモン動態とともに検 討を加えたので報告する。

\section{対象および測定方法}

I. 対象症例及び治療法（Table 1)

1975年 4 月より1981年 5 月までに当科に执いて入院
Table 1 Summary of urogenital cancer patients that have been studied.

\begin{tabular}{lccl}
\hline \multicolumn{1}{c}{ Type of tumor } & $\begin{array}{c}\text { Patients } \\
n\end{array}$ & $\begin{array}{c}\text { Age } \\
(\text { mean) }\end{array}$ & $\begin{array}{c}\text { Chemotherapy, } \\
\text { Radiotherapy }\end{array}$ \\
\hline Cancer of testis & 15 & $\begin{array}{c}22-46 \\
(32.8)\end{array}$ & VIB (3) CIA (1) \\
Radiation alone (11) \\
$\left\{\begin{array}{l}\text { Seminoma } \\
\text { Choriocarcinoma }\end{array}\right.$ & 11 & & \\
Embryonal carcinoma & 2 & & \\
Cancer of kidney & 15 & $28-71$ & VIB (3) MFC (4) CAF (2) \\
Cancer of urothelium & 33 & $\begin{array}{c}49-75 \\
(64.1)\end{array}$ & VIB (23) CAF (4) FOBEM (4) \\
Cancer of penis & & $60-77$ & Peplomycin (2) \\
& 2 & $(68.5)$ &
\end{tabular}

VIB : Vincristine, Ifosfamide and Bleomycin. CIA : CPDD, Ifosfamide and Adriamycin. MFC : Mitomycin. 5FU and Cytosine arabinoside. CAF: CPDD. Adriamycin and 5FU FOBEM : FT-207, Vincristine. Bleomycin, Cyclophosphamide and Mitomycin. AM Adriamycin and Mitomycin.

治療を行つた男子尿路性器悪性腫瘍患者65症例を対象 とした。

\section{1）殬丸腫瘍 15 症例}

年齢は $22 \sim 46$ 歳, 平均 32.8 歳である。病理組織学的 には seminoma 11例, choriocarcinoma 2 例, embryonal carcinoma 2 例である. 11例の seminoma 症 例は, UICC 分類 ${ }^{1}$ によれば $\mathrm{N}_{0} \mathrm{M}_{0} 10$ 例, $\mathrm{N}_{4} \mathrm{M}_{0} 1$ 例で あり，その治療法は全例 orchiectomy 後 $2,600 \sim 3,000$ rads の放射線療法のみ施行した。これに対し chor- 
iocarcinoma $\mathrm{N}_{4} \mathrm{M}_{1} 2$ 例, および embryonal carcinoma $\mathrm{N}_{2} \mathrm{M}_{0}, \mathrm{~N}_{4} \mathrm{M}_{1}$ に対しては放射線療法を実施せ ず, combination chemotherapyとして Vincristine, Ifosfamide, Bleomycin 93 者併用療法 ${ }^{2}$ （以下 VIB と略す） 3 例に行ない, 残る 1 例に Cis platinum (II) Diammine-dichloride (CPDD), Ifosfamide, Adriamycin(以下 CIA と略す)の 3 者併用療法を行な つた.

2）腎癌 15 症例

年齢は $28 \sim 71$ 歳, 平均 50.7 歳である.

Robson 改変分類 ${ }^{3}$ による staging では, stage I ： 5 例, stage II : 1 例, stage III : 3 例, stage IV : 6 例であり治療は, stage I , II については腎摘出術施行 後 4,000〜7,000rads の放射線療法を行ない, stage III, IVについては, palliative nephrectomyを施行したも のが 4 例あり， 9 例全例に放射線療法併用を含む制癌 剂療法が施行され，その内訳はVIB療法 3 例, Mitomycin C, 5-Fluorouracil, Cytosine arabinoside （以下 MFC と略す） 4 例, CPDD, Adriamycin, 5Fluorouracil（以下 CAF と略す）2 例である。

3）尿路上皮腫瘍 33 症例

その内訳は腎㙉腫瘍 4 例，尿管腫瘍 5 例，膀胱腫瘍 24 例であり, 年齢は $49 \sim 75$ 歳, 平均 64.1 歳であり, 全 例すべて進行尿路上皮腫瘍として手術, 化学療法, 非 特異的免疫療法が実施されて招り，そのうち25例には 放射線療法を併用した。

制癌剤による多剤併用療法としてVIB 療法が最も 多く23例に施行されている。放射線量はLinac 2,000 4,000rads, 一部症例で cobalt $\gamma$ 線 3,000 4,000radsであつた。

4) 陰茎癌 2 症例

症例は60歳及び70歳であり, UICC 分類 ${ }^{1}$ で $\mathrm{T}_{4} \mathrm{~N}_{0}$ $\mathrm{M}_{0}, \mathrm{~T}_{2} \mathrm{~N}_{0} \mathrm{M}_{0}$, 治療は Kracoff ら ${ }^{4)}$ の方法に準じて Peplomycin の持続点滴静注法を実施し， 1 例に Linac 5,000radsを併用した。

辠丸腫瘍及び尿路上皮腫瘍症例のうち follow up 対 象例については各成績の項で述べる。

\section{II. 検体採取法}

早期空腹時に时静脈よりへパリン採血を行ない，測 定に供するまでは $-70^{\circ} \mathrm{C} の$ deep frizeer に保存した. 採血時期については入院直後, 術後, 放射線療法・制 癌剂療法実施前後を原則とした。これらの治療中に副 作用軽減のため使用される antiemetics 及び時として 投与される各種合成ステロイドの視床下部・下垂体・
性腺系, 副腎系に及ぼす影響を考慮して採血時期は各 course 終了後 1 週間とした. 尚手術による stress のた めの gonadotropin, T, ACTH, F, DHA, DHA-S の動 態については副腎系及びTに拈いて48７2時間まで影 響が残り LH，FSH では変化がみられないといら報 告5) 7)があるため手術後採血は術後 1 週間を原則とし た.

また follow up 症例の採血時期については各成績の 項で述べる.

III. ホルモン測定法

LH, FSH, PRL 2 抗体法による radioimmunoassay（RIA） kitで測定した。Fについてはfree と bound の分離をポリエチレングリコールによる RIA kit で測定した。 Tについては，T-11 $\alpha \cdot$ succ-BSA を 抗原として作製された抗体（帝国藏器製薬）を用いた without chromatography ${ }^{8)}$, 及び一部症例に対して は125I-RIA kitにより測定した。

尚 without chromatography $と^{125}$ I-RIA kit 間に拉 ける丁值に関しては, $\mathrm{r}=0.984, \mathrm{Y}=1.09 \mathrm{X}-22.74$ $(n=45)$ と良好な相関を示した。 ACTHはdextran coated charcoal を利用した ${ }^{125} \mathrm{I}-\mathrm{ACTH}$ kit 使用し た。 DHA，DHA-S の測定は国分ら9の方法に準じた RIA 法で行なつたが, 測定法の詳細は既に教室の大橋

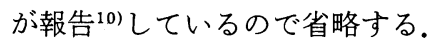

各種ホルモンの当教室に抢ける正常男子の mean士 S.D. は以下の如くである.

$\mathrm{LH}: 10.8 \pm 6.3 \mathrm{mIU} / \mathrm{ml}, \mathrm{FSH}: 9.6 \pm 6.7 \mathrm{mIU} / \mathrm{ml}$ $(\mathrm{n}=32$, age $5-80), T: 623 \pm 243 \mathrm{ng} / \mathrm{dl}(\mathrm{n}=18$, age 18-75), АСТH : $20 \sim 60 \mathrm{pg} / \mathrm{ml}(\mathrm{n}=20), \mathrm{F}: 12.6 \pm$ $4.9 \mu \mathrm{g} / \mathrm{dl}(\mathrm{n}=15$, age $24-75)$, DHA : $552 \pm 345 \mathrm{ng} /$ dl, DHA-S : $135.0 \pm 87.8 \mu \mathrm{g} / \mathrm{dl}(\mathrm{n}=15$, age $24-77)$, PRL : $11.7 \pm 4.8 \mathrm{ng} / \mathrm{ml}(\mathrm{n}=20$, age $20-82)$.

IV. 検查方法

1）ホルモン検査法

a) LH-RH テスト

合成 LH-RH（第 1 製薬） $0.1 \mathrm{mg}$ を静注負荷し静注 前, 30 分後にへパリン採血し LH, FSH を測定した。

b) rapid $\mathrm{ACTH}$ テスト

合成 ACTH (cortrosyn, 第 1 製薬) 25単位を生食 20 $\mathrm{ml}$ に溶解, 静注し 30 分, 60分後に DHA, DHA-S, F, T を測定した。尚前値は ACTH も含めて採血した。

c) clomiphene テスト

clomiphene citrate 1 日100mg を朝夕に分け連続 7 日間投与し, 前後の $\mathrm{LH}, \mathrm{FSH}, \mathrm{T}$ を測定した。 
Fig. 1 Plasma profiles of $\mathrm{LH}, \mathrm{FSH}$ and $\mathrm{T}$ in patients with testicluar tumor before and after therapy.

(- postoperative radiation, -0 combination chemotherapy, $n=13$ )

: mean \pm S.D. $* * P<0.01$ vs. basal level. HP $<0.001$ vs. normal level. $+\mathrm{P}<0.05$ vs. normal level.

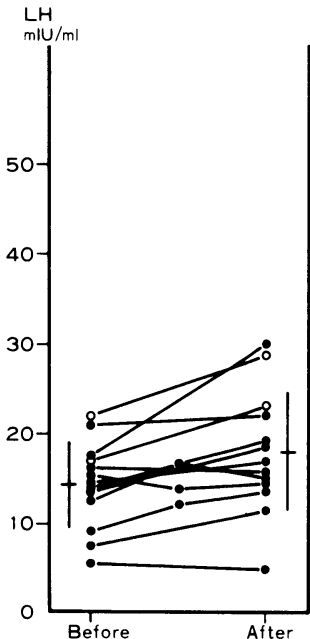

2）精子濃度及び睪丸生検

精液採取は 5 日間以上禁欲のら党用手的に行ない 60 分以内に検査した。また辠丸生検は，睪丸腫瘍症例の 一部に orchiectomy 時, 及び治療後 1 力月の時点で局 麻下にopen biopsy し, Bouin 氏液に固定後 Hematoxylin-Eosin 染色を行ない，組織学的分類につ いては市川, 熊本の分類法 ${ }^{11}$ を用いた. ホルモン検査及 び精子濃度測定の実施時期については前述した各種ホ ルモン測定時期に準じた。また HCG 産生 choriocarcinoma 2 例についてはいずれも遠隔転移を有してい たため LH, FSH 測定の対象外とした。

\section{成 績}

\section{I. 睪丸腫瘍症例（Fig. 1, 2, 3)}

放射線療法あるいは制癌剂療法を施行した15例中， HCG 産生の choriocarcinoma 2 例を除いた13例につ いて治療前術の LH, FSH, T 及び精子濃度・睪丸生検 を検討した。

治療前 $\mathrm{LH}$ は14.4 $44.6 \mathrm{mIU} / \mathrm{ml}$ (meas \pm S.D) であ り当教室に打ける正常男子 $10.8 \pm 6.3 \mathrm{mIU} / \mathrm{ml}$ との間 に差を認めなかつたが, FSH は $19.3 \pm 9.3 \mathrm{mIU} / \mathrm{ml}$ と 高值であり正常男子の $9.6 \pm 6.7 \mathrm{mIU} / \mathrm{ml}$ に比し有意の

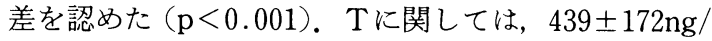
$\mathrm{dl}$ であり正常男子 $623 \pm 243 \mathrm{ng} / \mathrm{dl}$ に比して低值を示し た $(\mathrm{p}<0.05)$.

即ち放射線療法あるいは化学療法施行前に既に睪丸
Fig. 2 Plasma LH, FSH and T in patients with treated testis tumors during and following therapy.

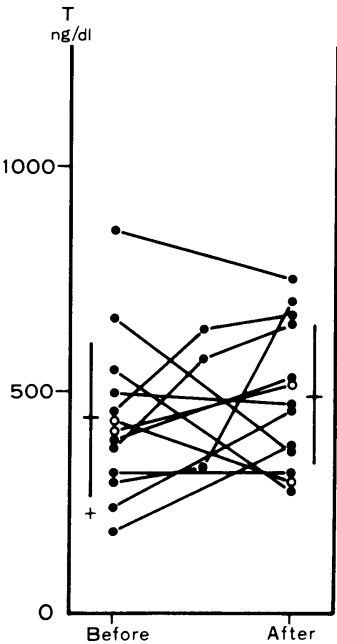

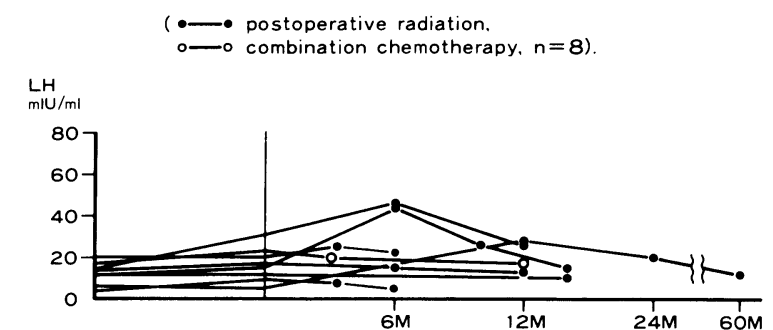

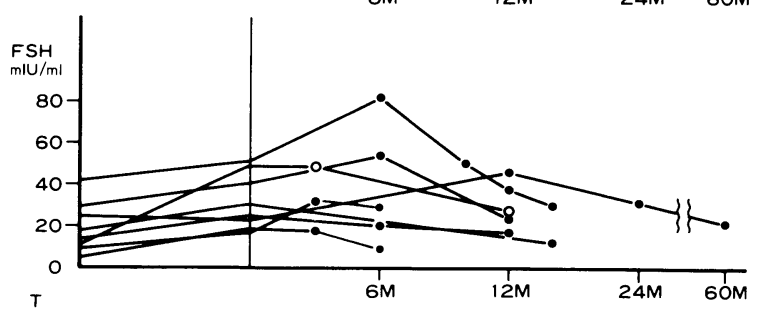

$\mathrm{ng} / \mathrm{dl}$

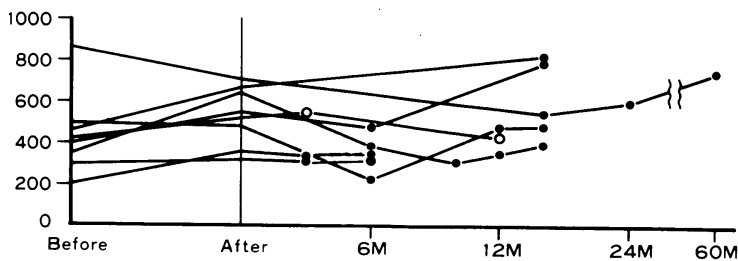

腫瘍患者の FSH は高値を示し，逆にTは低値を認め たことは興味ある知見であつた（Fig. 1). 
Fig. 3 Sperm count data in testicular tumor patients during and following therapy. $(n=9)$

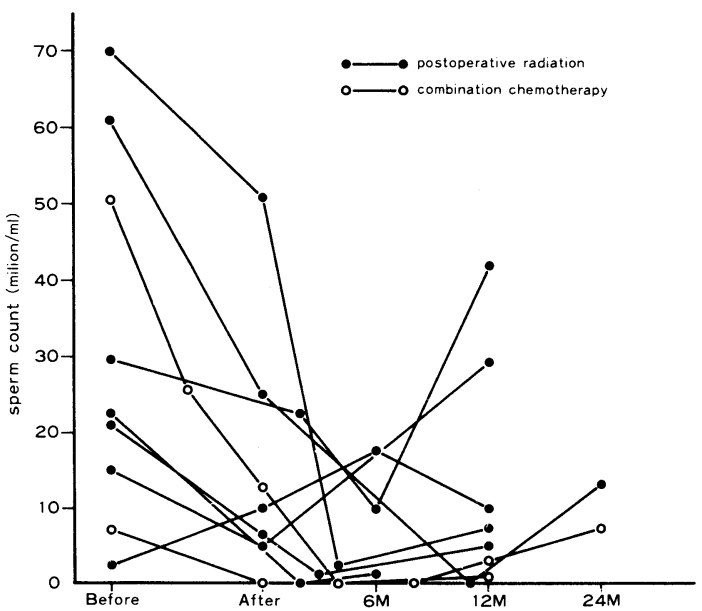

治療後の LH は $18.1 \pm 6.6 \mathrm{mIU} / \mathrm{ml}$ であり, 治療前 值 $14.4 \pm 4.6 \mathrm{mIU} / \mathrm{ml}$ の間に差はなかつたが，FSH に ついては治療後 $31.5 \pm 10.6 \mathrm{mIU} / \mathrm{ml}$ と, 治療前值 $19.3 \pm 9.3 \mathrm{mIU} / \mathrm{ml}$ に比して有意に高值を示した $(\mathrm{p}<$ 0.01). Tについては494 155ng/ảl であり, 治療前值 $439 \pm 172 \mathrm{ng} / \mathrm{dl}$ と差はなかつた。

個々の症例についてみると, 治療前後で LH はやや 上昇傾向があり FSH は全例上昇が認められたが，T は一定の傾向を示さなかつた. また少数例ではあるが,
化学療法単独群も放射線療法単独群と同様な傾向が治 療前後で見られた（Fig. 1).

放射線療法あるいは制癌剤療法を施行した睪丸腫瘍 症例の中治療終了後 6 力月以上 follow up 乙得た 8 例 につき, LH, FSH, T の推移を検討した。治療前後で 有意な上昇を認めた FSH は，治療終了後 6 力月の時

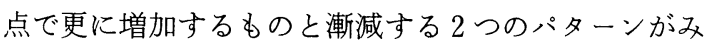
られたが, 12カ月の時点では, ほぼ治療前值に復した。 しかし治療前値そのものが既述した如く正常男子より 有意に高值にあるため尚 12 月の時点で健側責丸の精 細管に何らかの障害が残つていると推察された。 LH もFSH とほぼ同様の傾向を示したが，Tについては 一定の傾向は認めなかつた（Fig. 2).

殬丸腫瘍症例に抢ける精子濃度につき検討した。精 子濃度 $40 \times 10^{6} / \mathrm{ml}$ 以上を正常精子濃度, $10 \sim 40 \times 10^{6} /$ $\mathrm{ml}$ を乏精子濃度, $10 \times 10^{6} / \mathrm{ml}$ 以下を高度乏精子濃度 とすると治療前 9 例中 3 例のみが正常精子濃度を有し ていたにすぎず，残り 6 例は乏精子〜高度乏精子濃度 を示した，治療後では全例精子濃度の低下が認められ 治療終了後 $2 \sim 4$ 力月の時点で無精子症例を含めて最 低を示し, 治療後 12 力まで漸増する傾向が認められ たが，殆んどの症例で治療前精子濃度まで回復してい なかつた（Fig. 3).

5 例に施行した䁄丸生検に抢ける治療前後の検討で は，治療前 normal 1 例，III a 2 例，III b 2 例であつ

Fig. 4 Plasma profiles of LH, FSH and T in patients with renal cell carcinoma before and after combination chemotherapy. $(n=9)$
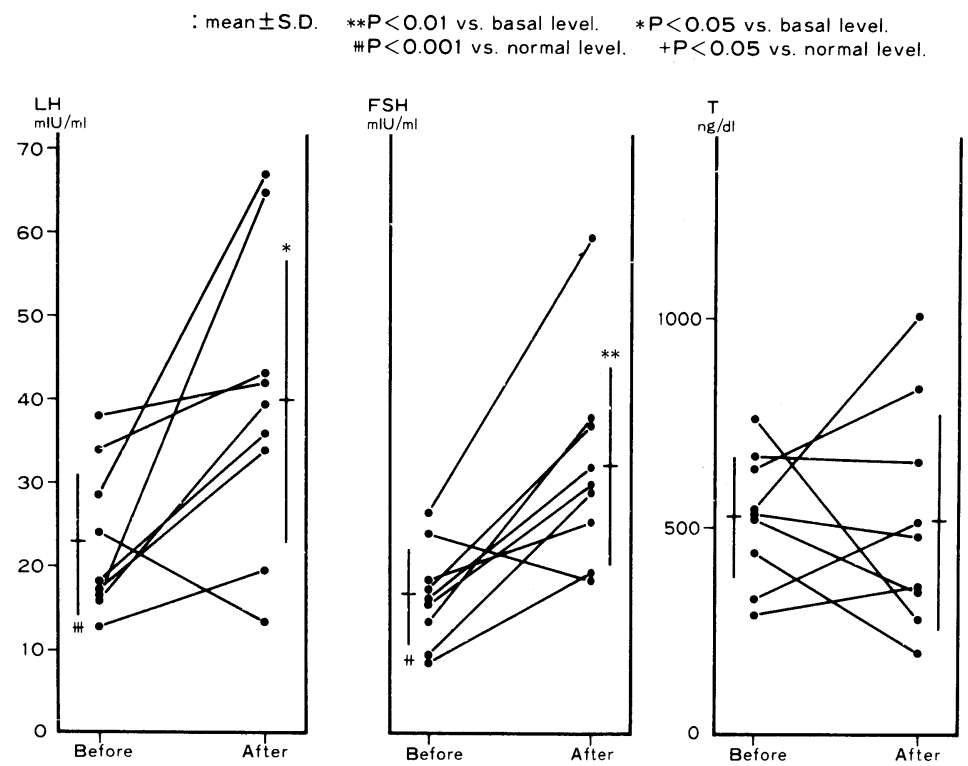
たが治療後 1 カ月の時点でII ～III a 4 例, III a 1 例と 精細管障害が明らかであつたが，間質は光顕レベルで は著変を認めなかつた。

II. 腎癌症例 (Fig. 4, 5, Table 2)

制癌剂療法単独または放射線療法併用群 9 例（平均 50 .9歳，46 66） と放射線療法単独群 6 例（平均 49.7 歳，28～71）の 2 群に分け治療前後の LH, FSH, T を 検討した。放射線療法併用を一部含む制癌剤療法群で は，治療前 LH，FSH，Tはそれぞれ $22.8 \pm 8.4 \mathrm{mIU} /$ $\mathrm{ml}, 16.6 \pm 5.6 \mathrm{mIU} / \mathrm{ml}, 527 \pm 145 \mathrm{ng} / \mathrm{dl}$ であり正常男 子に比し LH $(\mathrm{p}<0.001), \mathrm{FSH}(\mathrm{p}<0.01)$ で有意に高 值を示した.一方 Tについては差が認められなかつた。 LH，FSH の有意の上昇は対象症例の老化による影響 が推察された。治療後の LH, FSH, Tはそれぞれ $39.9 \pm 16.9 \mathrm{mIU} / \mathrm{ml}, \quad 32.2 \pm 11.5 \mathrm{mIU} / \mathrm{ml}, \quad 517 \pm 259$ $\mathrm{ng} / \mathrm{dl}$ であり, 治療前值との間で $\mathrm{LH}(\mathrm{p}<0.05), \mathrm{FSH}$

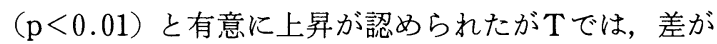
みられなかつた。

個々の症例についてみると LH，FSH で1例を除き 治療前後で上昇を示した (Fig. 4)。一方放射線療法単 独群における治療前 LH，FSH，Tはそれぞれ21.3土 $4.5 \mathrm{mIU} / \mathrm{ml}, 14.4 \pm 7.9 \mathrm{mIU} / \mathrm{ml}, 417 \pm 97 \mathrm{ng} / \mathrm{dl}$, であり 正常男子に比し LH $(\mathrm{p}<0.001)$ で高値, $\mathrm{T}(\mathrm{p}<0.01)$ で低値がみられた。これらの変化は加齢による影響に 個人差があるものと推察される。治療後の LH, FSH, T はそれぞれ $23.9 \pm 11.6 \mathrm{mIU} / \mathrm{ml}, 15.8 \pm 9.9 \mathrm{mIU} / \mathrm{ml}$,
Table 2 Changes in plasma LH, FSH and T in patients with renal cell carcinoma before and after therapy. $(n=15)$

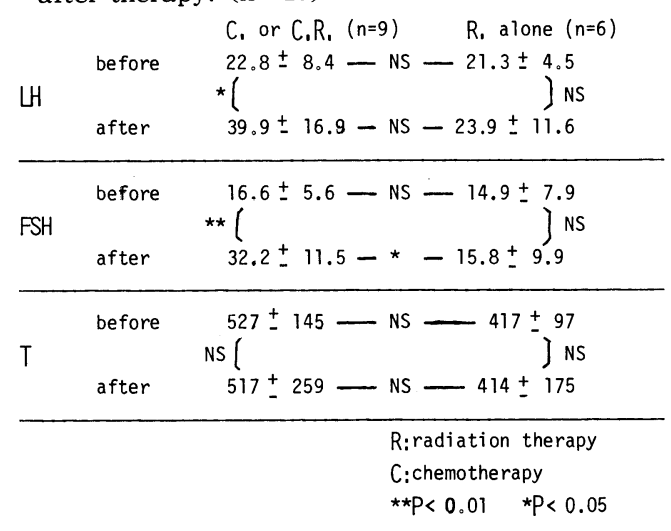

$414 \pm 175 \mathrm{ng} / \mathrm{dl}$ であり治療前值との間に全く差が認め られず，また個々の症例についても殆んど変化がなか つた (Fig. 5).

以上腎癌に抢ける治療群別検討では，Table 2 の如 く放射線療法単独では治療前後で LH, FSH に全く差 がみられなかつたのに対し放射線療法併用を含む制癌 剂療法では治療前後で有意な上昇を認めた。後療法と しての renal bedへの放射線療法単独では gonadotropin, $\mathrm{T}$ への影響は無視出来るものと思われ る.

III. 尿路上皮腫瘍及び陰茎癌症例（Fig. 6, 7-A, B,

Fig. 5 Plasma profiles of $\mathrm{LH}, \mathrm{FSH}$ and $\mathrm{T}$ in patients with renal cell carcinoma before and after radiation therapy alone. $(n=6)$

: mean士S.D. \#P<0.001 vs. normal level. \#P<0.01 vs. normal level.
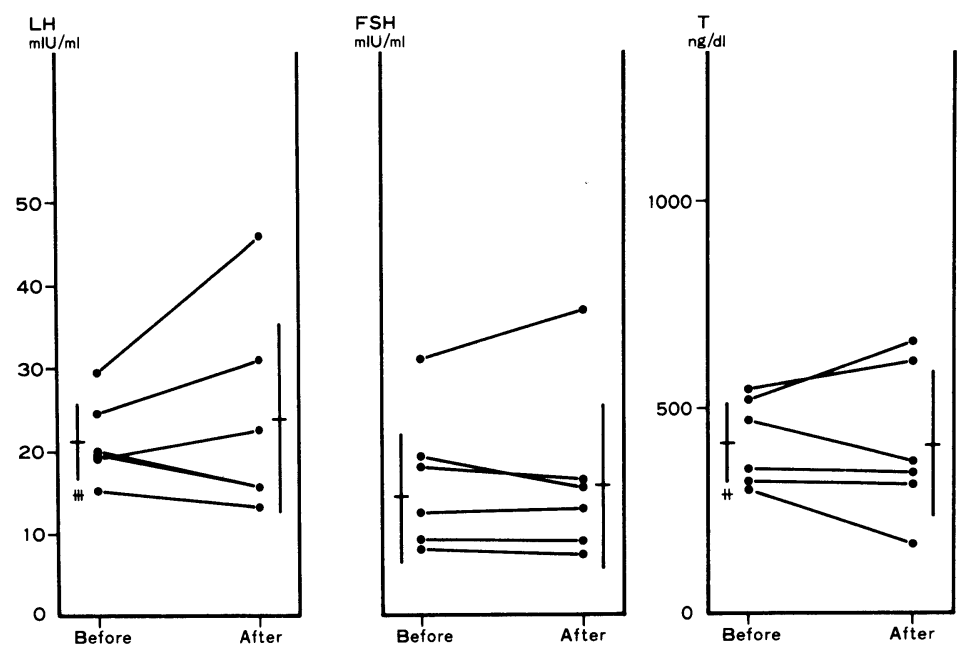
Fig. 6 Plasma profiles of LH, FSH and T in patients with urothelial cancer and penile cancer before and after chemotherapy alone or radiation. therapy in combination $(n=35)$

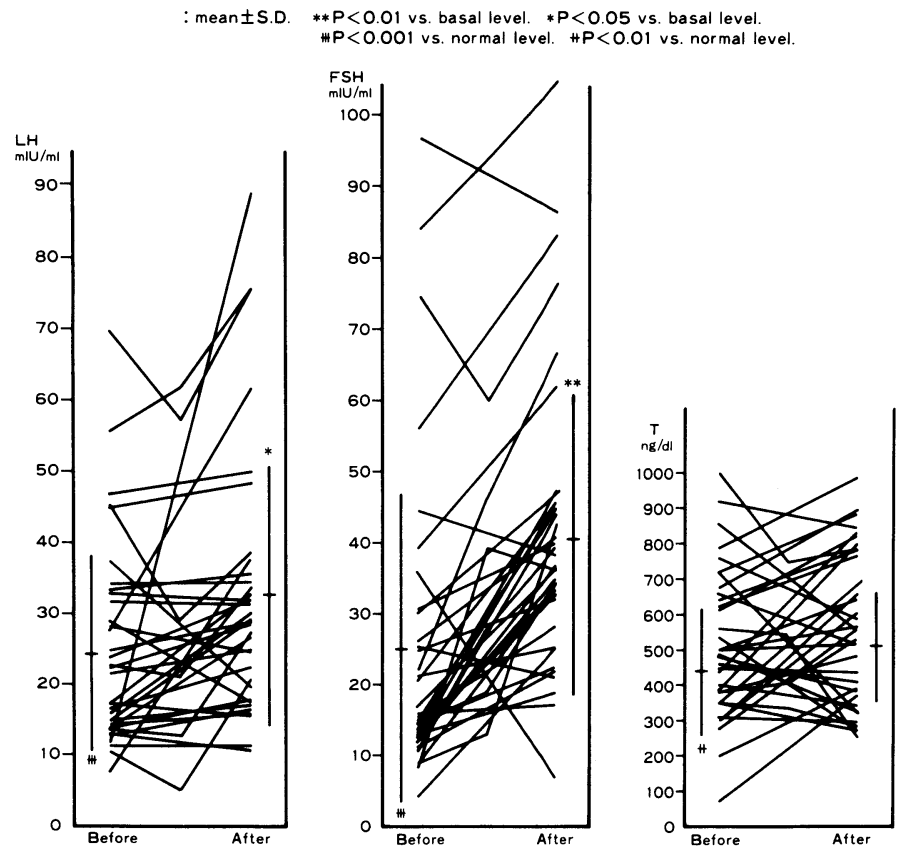

C)

治療法は Table 1 で示した如く制癌剂療法単独 9 例，放射線併用制癌剤療法26例であり，放射線療法単 独症例は除外した。治療前 $\mathrm{LH}$ は $24.5 \pm 13.7 \mathrm{mIU} / \mathrm{ml}$,

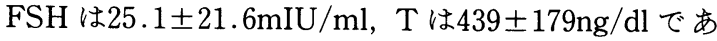
り正常男子と比較して LH, FSH で有意に高值を示し $(\mathrm{p}<0.001), \mathrm{T}$ では低值であつた $(\mathrm{p}<0.01)$.これらの 変化は腎癌症例之同様に対象症例の老化に伴うものと 考光た．治療前後での LH, FSH, T の推移をみると， $\mathrm{LH} 32.7 \pm 18.2 \mathrm{mIU} / \mathrm{ml}, \quad \mathrm{FSH}$ は $40.7 \pm 20.4 \mathrm{mIU} /$ $\mathrm{ml}, \mathrm{T}$ は $510 \pm 151 \mathrm{ng} / \mathrm{dl}$ であり前值と対比すると LH $(\mathrm{p}<0.05), \mathrm{FSH}(\mathrm{p}<0.01)$ で有意の上昇を認めたが, 一方下に関しては差がなかつた。

個々の症例についても LH, 特に FSH において殆ん どの症例で上昇傾向を示したが，Tについては治療前 後で上昇傾向を示すものと下降傾向を示すものが約半 数づつ認められた（Fig. 6).

これらの尿路上皮腫瘍及び陰茎癌症例において治療 後 3 力月以上follow up L得た18症例につき LH, FSH，T の推移をみた。血中 LH については，治療前 後で18例中上昇傾向を示したものが13例, 下降傾向を 示したものが 5 例あつたが, follow up 中に治療後 6
カ月以内に peak に達し以後漸減した。 な抬治療前後 で下降傾向がみられた症例も follow up 中に上昇を認 めており制癌剤, 放射線療法による影響に個人差が推 察された（Fig. 7-A). FSH については治療前後でほ 注全例に上昇傾向を認めたが，治療後の follow up 中 に LH と同様 6 力月以内に peak に達し以後漸減し, 12カ月の時点で治療前値に復するパターンがうかがえ た (Fig. 7-B). Tに関しては治療前後及び follow up を通じて一定の傾向はなく差が認められなかつた (Fig. 7-C).

IV. 尿路性器悪性腫瘍に対する VIB，および CAF 療法の影響 (Fig. 8, 9)

尿路性器悪性腫瘍症例に対して実施された多剤併用 療法は Table 1 に示した如くVIB 療法29例, CAF 療 法 6 例，MFC, FOBEM 療法各 4 例，その他 5 例であ つたが，この中症例数の多いVIB 及び CAF 療法につ き検討した. VIB 療法対象症例は尿路上皮腫瘍23例, 腎癌 3 例, 㬈丸腫瘍 1 例であり, CAF 療法対象症例は 尿路上皮腫瘍 4 例, 腎癌 2 例であり加龄の進んだ尿路 上皮腫瘍患者が多くを占めたため治療前 LH, FSH は 上昇傾向を認めたが，治療前後に抢ける LH, FSH, T については, VIB 療法, CAF 療法とも FSH の有意の 
上昇がみられた $(\mathrm{p}<0.05) . \mathrm{LH}$ については上昇傾向が 認められたが, 有意差はなく $\mathrm{T}$ 変化を示さなかつた。

V. 放射線療法を含む制癌剂療法の視床下部，下垂 体予備能に及ぼす影響について（Fig. 10A，B，Fig.

Fig. 7 Plasma LH, FSH and $\mathrm{T}$ in patients with treated urothelial cancers during and following chemotherapy.

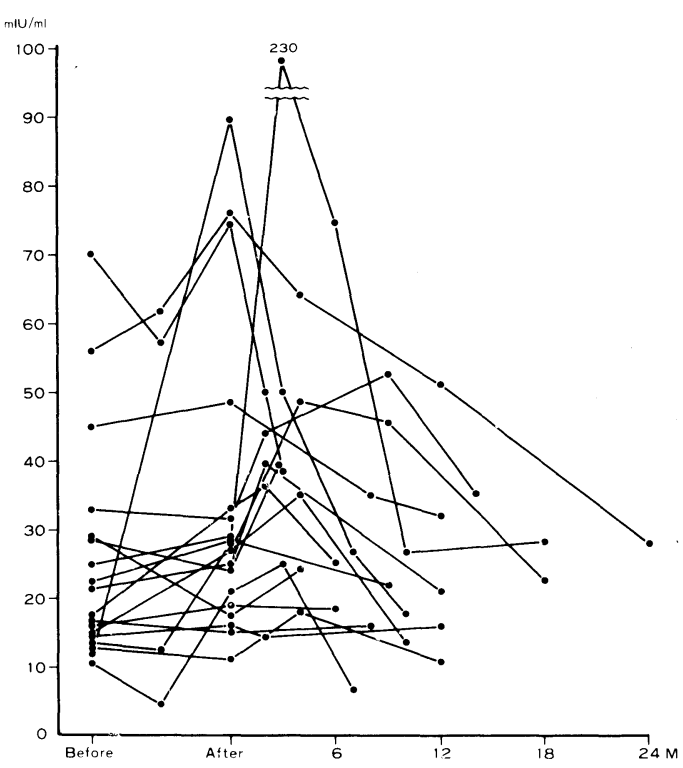

A) Plasma profiles of $\mathrm{LH}$

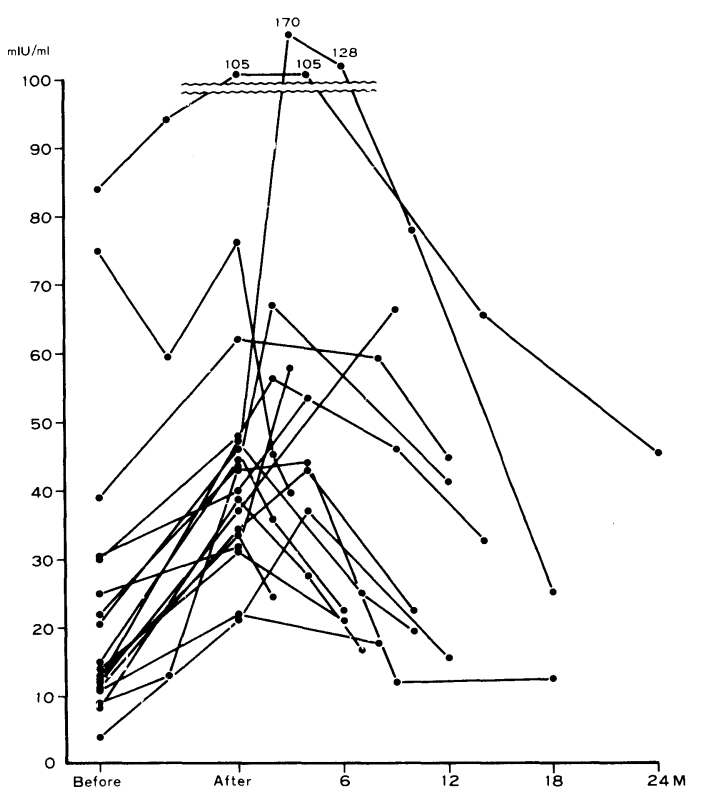

B) Plasma profiles of FSH

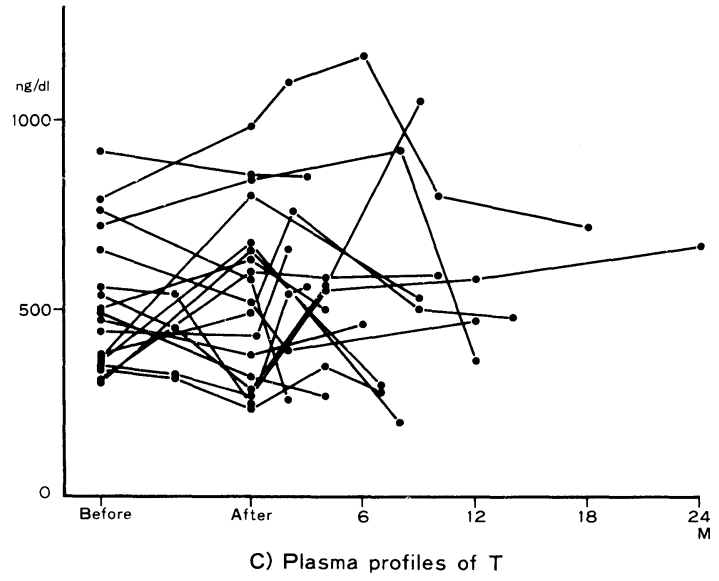

$11 \mathrm{~A}, \mathrm{~B})$

1) LH-RH テスト (Fig. $10 \mathrm{~A}, \mathrm{~B})$

対象は睪丸腫瘍 1 例, 腎癌 4 例, 尿路上皮踵瘍 17 例 の22例であり全例放射線併用を一部含む制癌剂療法が 実施されている。

治療前 $\mathrm{LH}$ の basal level は23.8 $213.7 \mathrm{mIU} / \mathrm{ml}$, FSH は24.8土22.8mIU/ml であり, LH-RH 負荷後 LH, FSH はそれぞれ $84.1 \pm 52.3 \mathrm{mIU} / \mathrm{ml}, 44.6 \pm 36.7$ $\mathrm{mIU} / \mathrm{ml}$ となり, Fig. 10B に示す如く治療前の反応率

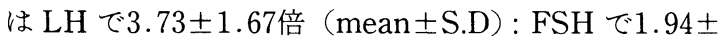
0.74 倍となり治療前の下垂体予備能は，正常に保たれ ていると考兄られる。治療後の LH の basal level 汢 $34.9 \pm 18.1 \mathrm{mIU} / \mathrm{ml}, \mathrm{FSH}$ は2.4 $18.1 \mathrm{mIU} / \mathrm{ml}$ であ り対象症例の治療前後の basal level の検討でも今ま で述べてきたように，LH $(\mathrm{p}<0.05) \mathrm{FSH}(\mathrm{p}<0.01)$ に上昇傾向が認められた。治療後にお打る LH-RH 負 荷の反応率は LH, FSH でそれぞれ5.59 3.89倍, $2.56 \pm 0.77$ 倍であり, 治療前後で LH-RH 負荷に対す る反応性は LH, FSH とも有意に増加 $(\mathrm{p}<0.05)$ を示 した事は, 制癌剤投与により下垂体 gonadotoropin 放 出が充進した事が示唆された。

2) Clomiphene テスト (Fig. 11A, B)

放射線療法を含を制癌剤療法が施行された腎癌 2 例, 尿路上皮腫瘍 7 例を対象として, 治療前後に clomiphene citrate $100 \mathrm{mg}$ を連続 7 日間投与し，投与 前後の LH, FSH, T を検討した. 対象 9 症例の治療前 後における basal level の検討では FSH にのみ上昇 を認めた $(\mathrm{p}<0.05)$. 治療前後に括ける反応性は $\mathrm{LH}$, FSH, T のいずれも差がなかつた。

LH-RH clomiphene citrate 負荷による視床下部下 
Fig. 8 Plasma concentrations of LH, FSH and $\mathrm{T}$ in patients treated with Vincristine, Ifosfamide and Bleomycin combination chemotherapy.
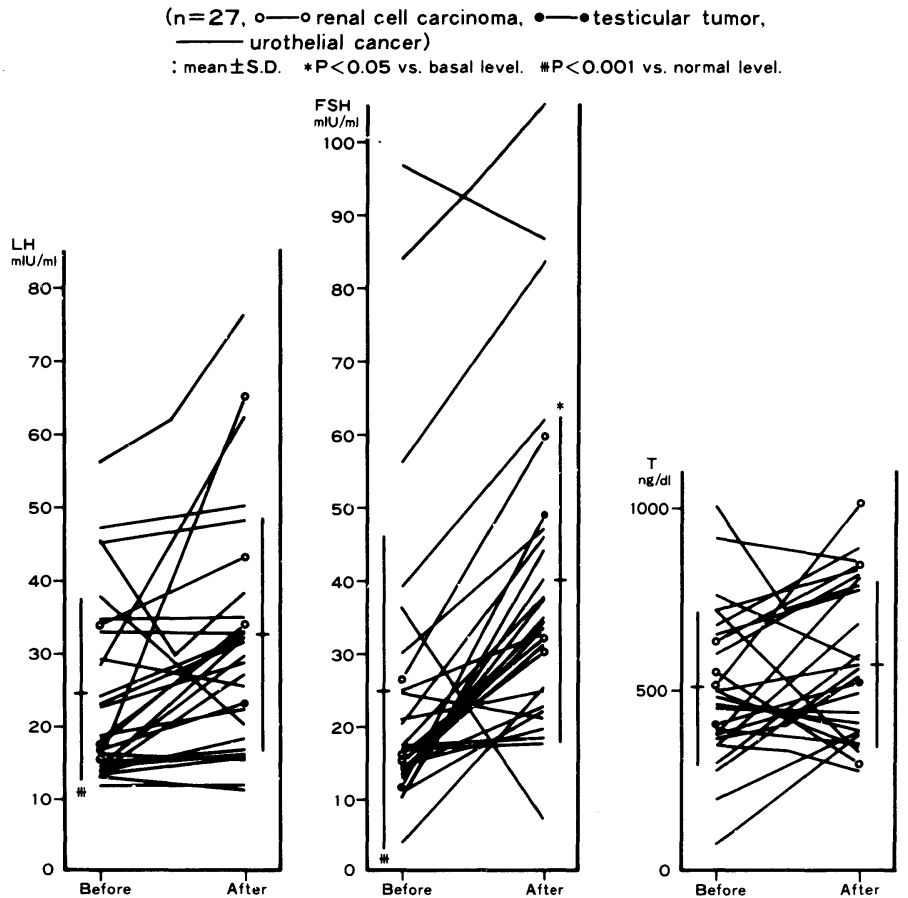

Fig. 9 Plasma concentrations of LH, FSH and $\mathrm{T}$ in patients treated with Adriamycin, 5Fluorouracil and CPDD combination chemotherapy.

( $n=6$, o- orenal cell carcinoma, urothelial cancer)

: mean \pm S.D. $* P<0.05$ vs. basal level. $\mathrm{PP}<0.001$ vs. normal level.
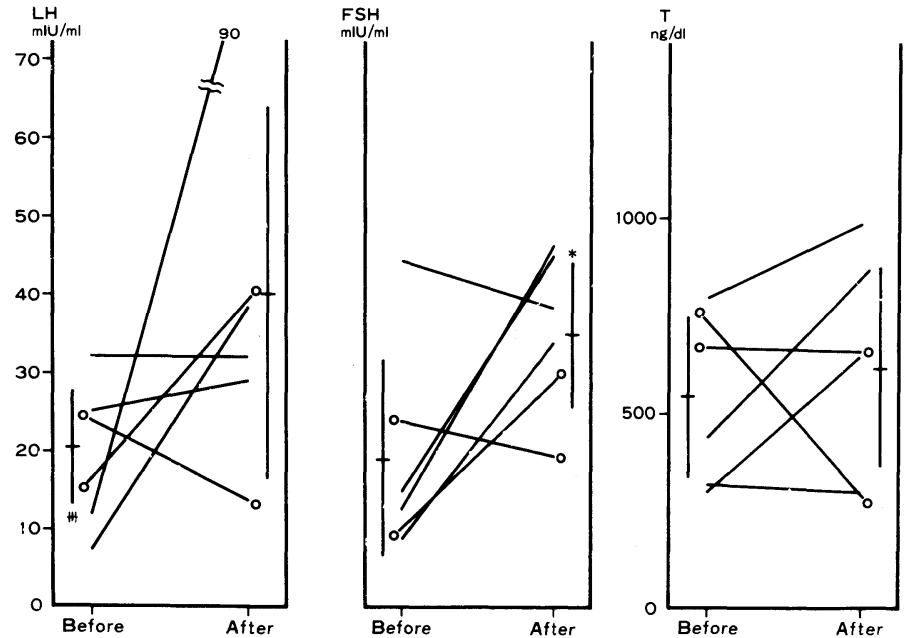

垂体の反応については，放射線療法を含む制癌剤療法 前後で少なくともその予備能力の障害は認められない と考える。

VI．放射線療法を含む制癌剂療法の副腎系に及ぼ
す影響について（Table 3, Fig. 12A, B)

副腎性 androgen である DHA, DHA-S のの影響に ついては，殆んど報告がないため今回血中 T, ACTH 及び glucocorticoid である Fを含めて測定し検討を 
Fig. 10 A) Response of plasma LH, FSH to LH-RH administration in genitourinary cancer patients treated with chemotherapy. $(n=22,4$ renal cell carcinoma, 17 urothelial cancer, 1 testicular tumor)

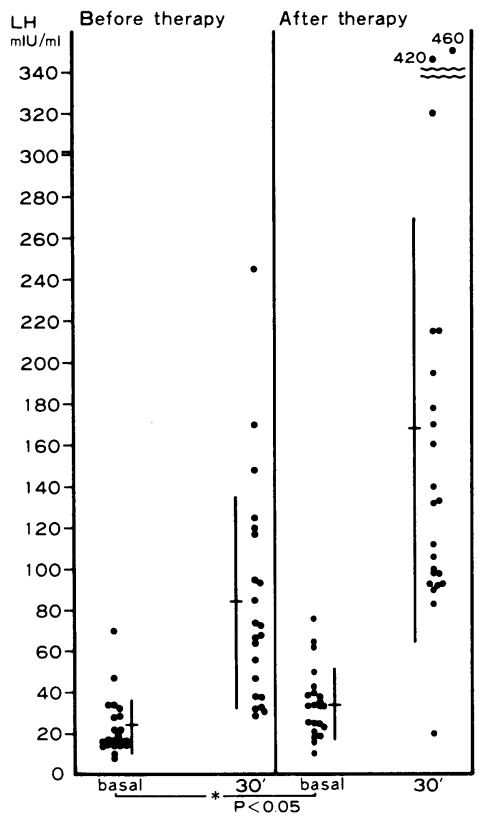

Fig. 10 B) Changes in response ratio after $\mathrm{LH}$ RH administration.
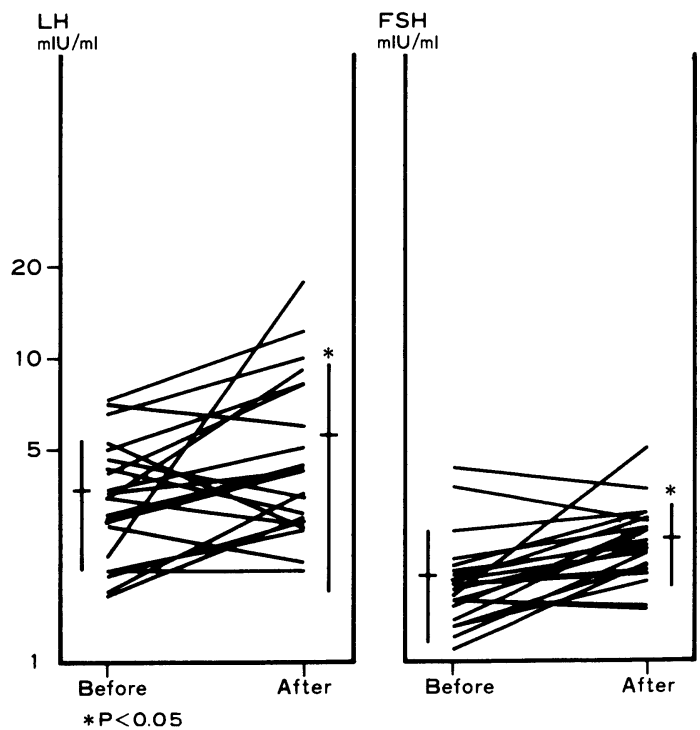

加えた。

対象は辠丸腫瘍 4 例，腎腫瘍 3 例，尿路上皮腫瘍 6 例であり放射線療法のみ施行した seminoma 3 例を

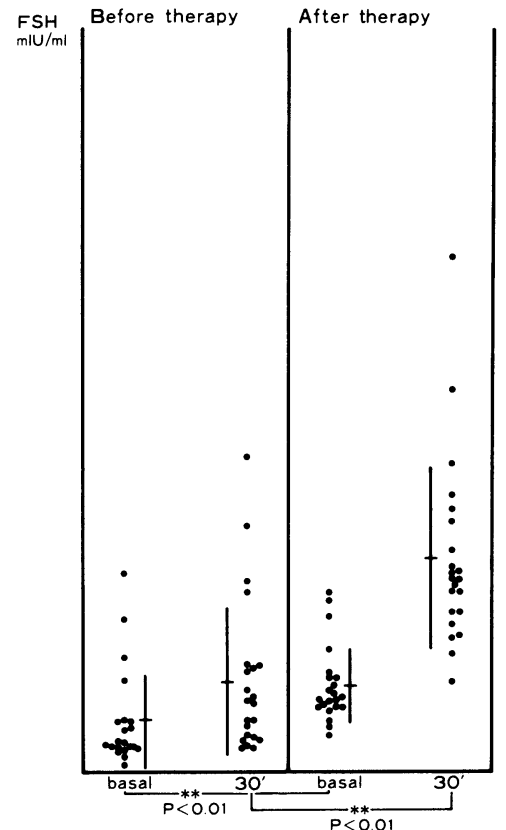

Table 3 Plasma concentration of ACTH, DHA, DHA-S, $T$ and $F$ in patients with urological malignancy before therapy.

\begin{tabular}{|c|c|c|c|c|c|}
\hline Case (age) & $\begin{array}{l}\text { ACTH } \\
\mathrm{pg} / \mathrm{ml}\end{array}$ & $\begin{array}{l}\text { DHA } \\
\mathrm{ng} / \mathrm{d} \mathrm{l}\end{array}$ & $\begin{array}{c}\text { DHA-S } \\
\mu \mathrm{g} / \mathrm{d} l\end{array}$ & $\begin{array}{c}T \\
\mathrm{ng} / \mathrm{d} \mathrm{l}\end{array}$ & $\begin{array}{c}F \\
\mu g / d l\end{array}$ \\
\hline \multicolumn{6}{|l|}{ * Cancer of testis } \\
\hline 1) Seminoma(41) & 16.5 & 274 & 151.0 & 310 & 6.8 \\
\hline 2) Seminoma(46) & 10.0 & 216 & 41.7 & 220 & 9.4 \\
\hline 3) Semimoma (37) & 21.2 & 369 & 388.9 & 196 & 13.3 \\
\hline 4) Choriocarcinoma (32) & 46.7 & 294 & 147.3 & 316 & 9.7 \\
\hline \multicolumn{6}{|l|}{ * Cancer of kidney } \\
\hline 1) Cancer of kidney(28) & 38.1 & 352 & 140.6 & 516 & 12.5 \\
\hline 2) Cancer of kidney $(60)$ & 11.6 & 313 & 315.5 & 446 & 3.4 \\
\hline 3) Cancer of kidney(57) & 68.0 & 453 & 335.5 & 350 & 6.4 \\
\hline \multicolumn{6}{|l|}{ * Cancer of bladder } \\
\hline 1) Cancer of bladder(75) & 14.9 & 183 & 62.0 & 71 & 12.0 \\
\hline 2) Cancer of bladder(64) & 49.5 & 246 & 28.9 & 201 & 12.6 \\
\hline 3) Cancer of bladder(71) & 26.7 & 337 & 23.9 & 640 & 15.8 \\
\hline 4) Cancer of bladder(64) & 46.2 & 396 & 155.0 & 426 & 13.6 \\
\hline 5) Cancer of bladder(64) & 10.0 & 518 & 268.0 & 860 & 5.7 \\
\hline * Cancer of penis (77) & 39.9 & 323 & 40.9 & 620 & 15.2 \\
\hline
\end{tabular}

除く10例に対し制癌剂による治療がなされている，治 療前の DHA は $330 \pm 90 \mathrm{ng} / \mathrm{dl}$ であり正常男子の $552 \pm$ $345 \mathrm{ng} / \mathrm{dl}$ に比し低值を示したが $(\mathrm{p}<0.05)$, 同年齢の 正常男子に比し殬丸腫瘍症例では平均 $288 \mathrm{ng} / \mathrm{dl}$ と低 值が認められた。 DHA-Sについては治療前值は $161.5 \pm 121.9 \mu \mathrm{g} / \mathrm{dl}(23.9 \sim 388.9 \mu \mathrm{g} / \mathrm{dl})$ であり $\mathrm{F}$ は 
Fig. 11 A) Response of plasma LH, FSH and T to clomiphene citrate administration in patients with combination chemotherapy. ( $n=9,2$ renal cell carcinoma, 7 urothelial cancer)

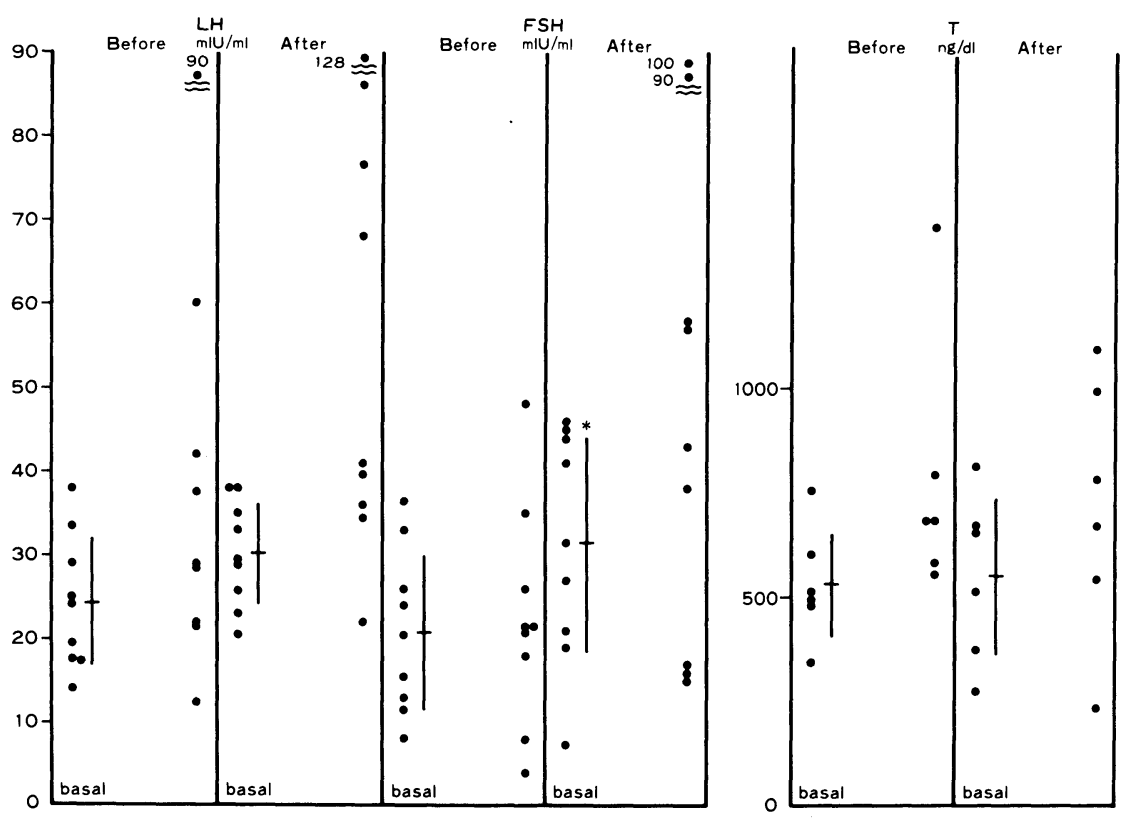

Fig. 11 B) Changes in response ratio after clomiphene citrate administration.
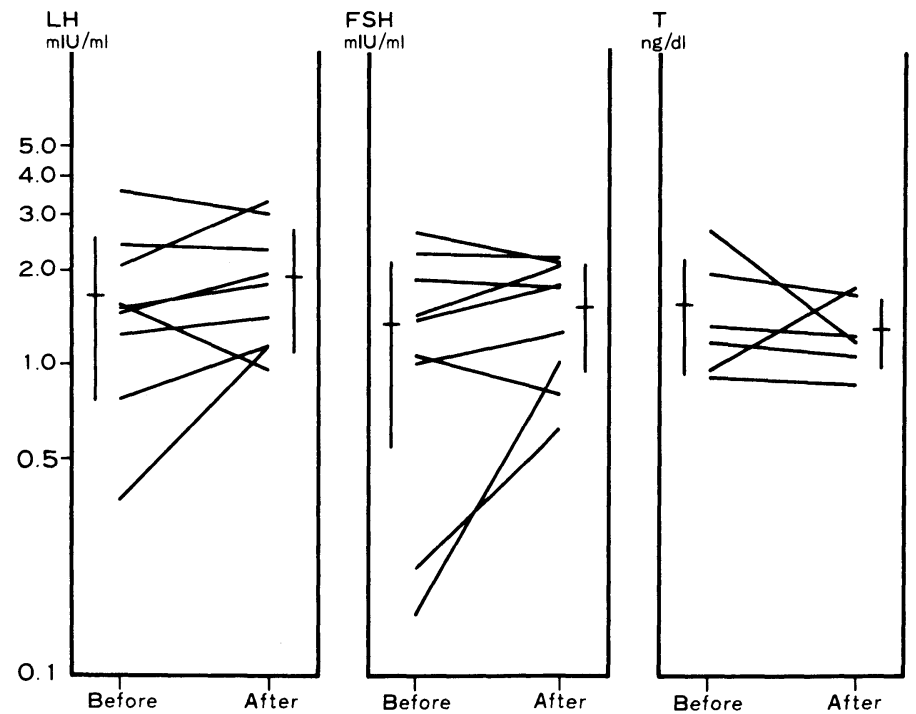

$10.5 \pm 3.8 \mu \mathrm{g} / \mathrm{dl}$ いずれも正常範囲にあつたが, DHA$\mathrm{S}$ の変動が大きく, 老化もしくは全身状態の悪化した 尿路上皮腫瘍症例に低值が認められた. Tにおいては, $398 \pm 210 \mathrm{ng} / \mathrm{dl}$ と正常男子に比し低値を示した（ $\mathrm{p}<$ 0.05).これは既に検討した如く粹丸腫瘍, 尿路上皮腫
瘍に打ける治療前下値の低下によるものと考兄るが, いずれにしても殬丸腫瘍症例で, 治療前 DHA, T の低 值を認めた事は興味ある知見であつた（Table 3). 放射線療法を含む制癌剂療法による治療前後で DHA, DHA-S, T, F, ACTH に差があるか否かを検討 
Fig. 12 A) Response of plasma DHA, DHA-S, T and F to rapid ACTH stimulation in patients with urogenital malignancy before $(\bullet-\bullet)$ and after $(\mathrm{O} \cdots$ O) chemotherapy.

$(\mathrm{n}=13,3$ renal cell carcinoma, 6 urothelial cancer, 4 testicular tumor) : mean \pm S.D. $+\mathrm{p}<0.05$ vs. normal level.
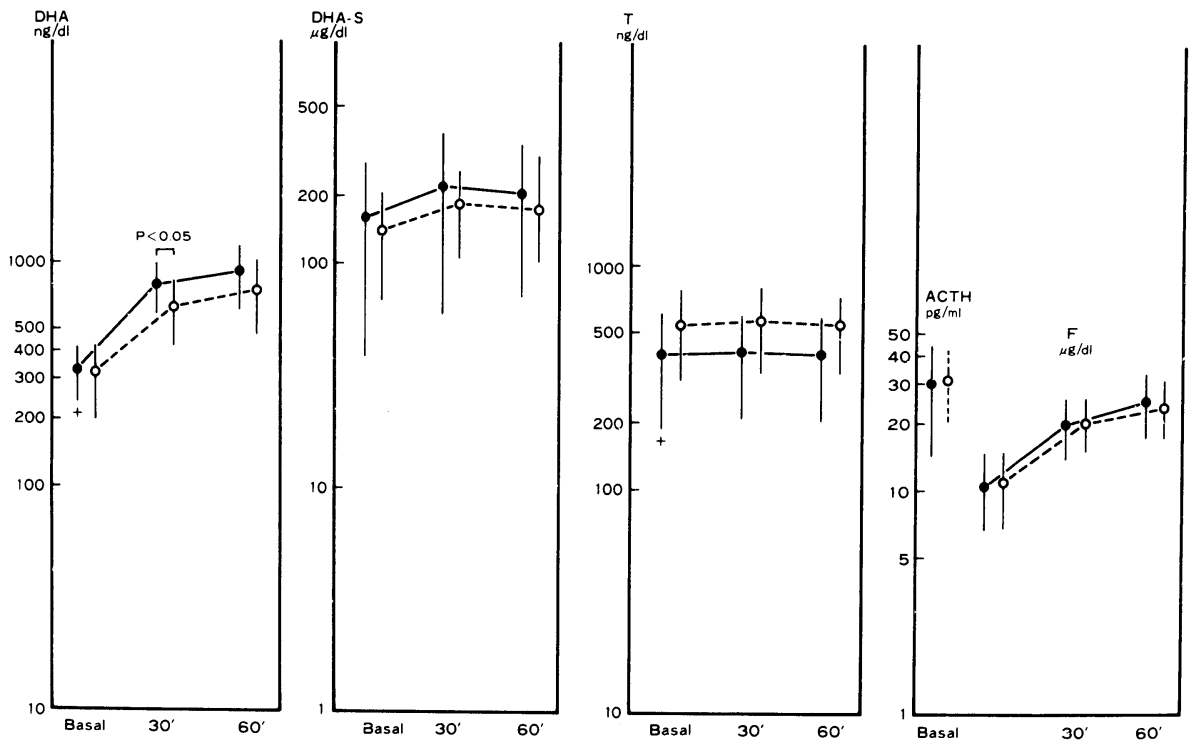

Fig. 12 B) Changes in peak/basal ratio after rapid $\mathrm{ACTH}$ stimulation.

Peak/basal ratio

Fig. 13 Plasma profiles of PRL in patients with urogenital malignancy before and after chemotherapy.

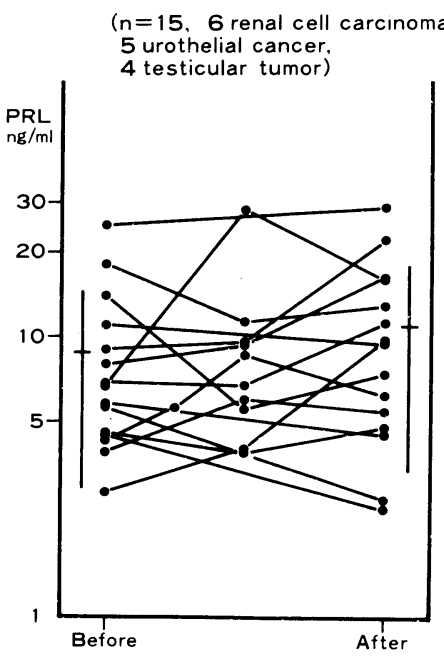

したが，いずれにおいても差は認められなかつた。更 に合成 ACTH を負荷して治療前後の副腎皮質機能を 対比したが，DHAの30分值に有意差を認めたのみで あり基礎值に対する peak 值の ratioにおける検討で も治療前後で有意差はなく副腎皮質予備能の障害は認 められなかつた。

VII. 制癌剤療法前後の PRL の変化について（Fig. 13).

泌尿器科領域の担癌患者で血中 glycoprotein と関 連してPRLの上昇がみられたといら報告 ${ }^{22}$ や Hodgkin's disease に打ける制癌剂投与により thyroid stimulating hormone (TSH) と PRLの上昇 
を来たしたとする報告 ${ }^{13)}$ もあるため, 今回15例(腎癌 6 例，尿路上皮腫瘍 5 例，睪丸腫瘍 4 例）を対象として 治療前後の PRL 值を検討した。治療前 PRL は8.8土 $5.9 \mathrm{ng} / \mathrm{ml}$, 治療後 $10.7 \pm 7.3 \mathrm{ng} / \mathrm{ml}$ であり,いずれも正 常男子に比較して全く差が認められなかつた。個々の 症例についても治療前後で一定の傾向はみられず，腎 癌の 1 例の夕治療前より軽度上昇を認めたにすぎず， HCG 産生の choriocarcinoma 1 例を含む殬丸腫瘍症 例 4 例はいずれも正常範囲内に変動を示した。

\section{考按}

\section{I. 制癌剂の及ぼす影響}

制癌剤による辠丸機能低下特に精細管障害について は, alkylating agents及び plant alkaloidsにおいて 比較的多くの検討がなされている ${ }^{14)}$.

制癌剤としての歴史の古い alkylating agentsにつ

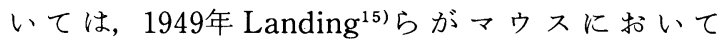
Mechlorethamine の精細管障害を報告し，また臨床上 使用機会の多いCyclophosphamide

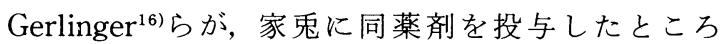
gonocyte が激減したと述べている。 その他の alkylating agentsである Thiotepa も動物実験で同様な精細 管障害を惹起することが知られている17).

人の辠丸機能に対する cyclophosphamide の影響に ついては悪性腫瘍, nephrotic syndrome が対象疾患と なつて打り, Fairely ${ }^{18)}$ ら成人の nephrotic syndrome 患者に 1 日50～100mg を投与し経過を追い ながら精子濃度を観察したところ投与後 3 週間で低下 が認められ， 4 力月後 31 人中 18 人に， 6 力月後全例に 無精子症が発現したと報告している。また Kumar ${ }^{19}$ ら も同疾患患者 8 名に $3 \mathrm{mg} / \mathrm{kg} / \mathrm{day}$ で 6 力月以上投与 し， 2 〜 28 力間の休薬期間を経てもな扮 6 名が殬丸 生検で germinal cell aplasia, 2 名に spermatogenic arrestを認めたと述べており，さらに Leydig cellに は何ら組織学的に障害が認めなかつたと報告してい る。

一方思春期前もしくは思春期に和ける cyclophosphamideの睪丸機能に及ぼす影響については投与量 及び投与期間だけでなく成人と違つてその使用開始年 齢にも関係があり，思春期前の immature testes では， spermatogenesis が活発化している思春期の辠丸に比 し萎縮を起しにくいといわれている20).これに関連し $て$ Kirkland $^{21)}$ ら思春期に cyclophosphamideによ る治療を受けた患者で血中 LH，FSH を測定したとこ ろ同年齢に比して有意の上昇が認められ，更に LH-
RH 負荷テストでも反応性の増加を来たしたとし，原 発性睪丸障害を警告したが，しかしTについては正常 範囲であつたと報告している。

単独投与されたその他の alkylating agentsに上る 人睪丸に打ける検討については, Busulfan ${ }^{22)}$, Mechlorethamine $^{23)}$, Thiotepa ${ }^{24)}$, Chlorambucil ${ }^{25)} V$ おいてもCyclophosphamide と同様な精細管障害が 知られている。特に Guesry ${ }^{26)}$ らは思春期又は思春期前 にChlorambucilによる nephrotic syndrome 治療後 の血中 LH, FSH, T 測定，精液検査を行ない，21例中 17例に無精子症， 2 例に高度乏精子症が発生し，精細 管障害による FSH の有意の上昇を13例に認めたが， LH, T は変化を示さなかつたとしている.

次に plant alkaloidであるVinblastine について は，Vilar ${ }^{14)}$ が 8 名の患者に 1 日 $10 \mathrm{mg}$ を $1 \sim 5$ 週間使 用したところ， 8 名中 6 名に乏精子症を認めたと報告 しているが，血中 gonadotropin，T は影響を受けなか つたとしている。一方 Vincristine に関しては単独投 与による gynecomastia の報告 ${ }^{27)}$ はるが，直接人睪 丸機能障害について言及した文献は著者が調べ得た範 囲ではなかつた。

antimetabolitesについては, 6Mercaptopurine（6 MP) ${ }^{28)}, \quad 8-A z a g u a n i n e^{17) 28)}, \quad$ Cytosine arabinoside $^{29 / 30)}$, Hydroxyurea ${ }^{29 / 30)}$ とよる動物での精 細管障害が知られているが，人辠丸機能に及ぼす影響 を検討したものは少なく，Methotrexate（MTX）に ついてなされているのみである。しかし psoriasis 症 例でMTX 投与後男性不妊をひき起したとする報 告 ${ }^{31)}$ がある反面, 治療前後で精液検査, 辠丸生検を実施 しても全く異常がなかつた ${ }^{32)}$ とする報告もあり， MTX の精細管障害については一定した見解が得られ ていない。

$5 \mathrm{Fu}$ による人辠丸機能障害の報告はないが，雌ラッ トに扮ける卵巣重量の低下と血中 Estrone, Estradiol の上昇を認めたとする報告はある ${ }^{33)}$.

Antitumor antibioticsについては, Mitomycin Cで マウス辠丸に対する障害を伊藤 ${ }^{28}$ が報告し，

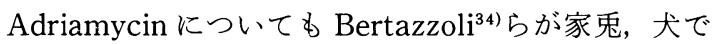

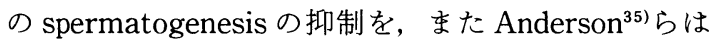
ラットに怙ける stem cell, Sertoli cell の障害が nontoxic dose で起ると述べている. Bleomycin について もラット䁄丸での spermatogenesis の障害の可能性 が示唆されている30).

その他の制癌剂である Procarbazine は, Hodgkin' 
s disease に対する多剂併用療法 $\mathrm{MOPP}^{36)}$ の一環とし て頻用されているが，マウスでの精細管障害が知られ ており ${ }^{29)}$ また最近の新しい制癌剂である CPDD, Ifosfamide に関してもそれぞれ動物実験レベルで, spermatogenesis が抑制されたとする報告が散見され $3^{37) 38)}$.

単独投与された各種制癌剤が, 人殬丸における spermatogenic cycle のどの段階で影響を及ぼすのかを直 接知ることは困難であるためそれらの検討は，いきお

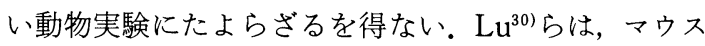
辠丸における 7 種の制癌剤の影響を検討した結果 Adriamycin, Cyclophosphamide, Cytosine arabinoside, Hydroxyurea, Bleomycin, Vinblastine, Vincristineのすべての薬剤に対して differentiated spermatogonia が最も感受性が高く, Adriamycin を 除く 6 種の制癌剂に対し stem spermatogonia 及び preleptotene 以後の spermatocytes, spermatids は抵 抗を示したとしており，個々の制癌剤の spermatogenic cellsへの影響にはそれぞれの cytotoxic actionの差異に基づくスペクトラムの相違があると

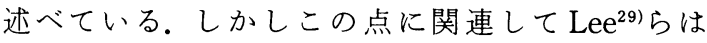
cytosine arabinoside が spermatogoniaに括ける DNA 合成を阻害するが，これはDNA polymerase inhibitor としての作用によるものと推察し, Cyclophosphamide spermatogonia の DNA 合成と early-elongated spermatids $の$ RNA 合成を障害し Vincristine はDNA，RNA 合成障害だけでなくlate elongated spermatids の protein 合成まで影響を及ぼ すと述べ $\mathrm{Lu}^{30)} ら の$ 見解と相違している。しかし動物実 験に拈ける単一制癌剤の spermatogenic cells に対す る dose は $\mathrm{LD}_{50}$ あるいは maxinally tolerated dose (MTD)に近く，かつ single shotでありそのまま人の 辠丸機能に対する障害として理解することは出来ない が，Lu ら ${ }^{30)}$ による動物実験では, 通常の臨床使用量で の換算に打いて Adriamycin, Cyclophosphamide, cytosine arabinoside, Hydroxyurea で differentiated spermatogonia に障害が認められ，特に Adriamycin ではstem cellにも重大な影響が起ると述べている。 したがつて作用機序だけから考劣るなら Adriamycin と同様いわゆる DNA dependent RNA polymerase inhibitor である Daumomycin, Actinomycin D に関 しても人殬丸障害の可能性もあると推察される。

II. 放射線療法の及ぼす影響

一方 radiation による精細管障害については, DNA
合成が障害されるためには differentiated spermatogonia 及び preleptotene primary spermatocyte が最も影響を受ける。その結果としてそれ以下の spermatocytes, spermatids の枯渴を招くとされている399. Single dose として600rads 以内であれば精細管障害 は reversibleであるが，200radsを越すと radiation 後 prolonged aspermia をひき起し完全回復まで 5 年 以上を必要とするといわれている40). しかし臨床上睪 丸機能障害に与える radiation の影響を検討する場 合, single doseよりも fractionated doseの方がはる かに重大であり，その dose も single dose に比較して 小線量で問題を生じる ${ }^{41)}$ ４6). 一般に Hodgkin's disease に対する inverted Y pelvic radiation では辠丸 への fractionated dose は140 300 rads $^{42}$ あるいは total dose の $4.0 \sim 4.4 \%{ }^{44)}$ と報告されており，また seminoma $の$ 場合 の dog-shaped radiation では $90 \sim 150 \mathrm{rads}^{4143}$, 前立腺癌での radiation therapy で serinoma 症例の $2 \sim 3$ 倍量 ${ }^{40)}$ あるいは $250 \sim 500 \mathrm{rad}^{47)}$ の scattered dose が睪丸へ影響を及ぼすとされてい る.

自験例の場合 radiation 単独の腎癌症例について は, 照射野である renal bed からの睪丸への scattered fractionated dose は無視出来るものと考兄るが, 通常 の dog-shaped areak平均 $2,800 \mathrm{rads}$ 照射した seminoma 症例及び膀胼部を含む骨盤内へ平均 3,000 rads 照射した尿路上皮腫瘍症例に拈ける辠丸への fractionated dose は, seminoma で約100rads, 尿路上 皮腫瘍で約150２00rads と推定される。睪丸への fractionated dose と精子濃度について Sandeman ${ }^{48)}$ は，睪丸腫瘍症例を対象として検討しており，それに よると，35rads 以上で aspermia が発生し，50〜100 radsでは 8〜26力月後より回復が始まり，105〜160 rads では13〜38カ月, 210 312rads では12〜14年経て ようやく回復して来ると述べているが, $\mathrm{Ash}^{46)}$ む 200 radsを越すと aspermia は permanent であり得ると 報告している。自験例の seminoma 症例では radiation therapy 後 $2 \sim 4$ カ月で aspermia を含めて精子 濃度は最低となり 12 カの時点でなお治療前值に復し て打らず，また睪丸への fractionated doseが約 100 rads と推定されることょり, 完全回復までには更に数 カ月〜十数力月を要すると考劣る。自験例の尿路上皮 腫瘍患者では, 少なくとも seminoma症例よりも fractionated dose は多く，かつまた泌尿器科領域に揖 ける通常の X-ray 検査でも2 10rads づつの辠丸への 
scattered dose $\mathrm{e}^{49)}$ があることを考慮すると回復まで数 年を要すると推定される。しかし文献上辠丸への scattered fractionated dose と精子濃度との関係につ いての検討は殆んどが比較的若年者を対象としてなさ れたものであり ${ }^{42) 44(48),}$ 老年者での精子濃度の回復パ ターンにそのままあてはめて考觉る事には無理がある と思われる。

III. 放射線治療を含む，多剂併用療法の及ぼす影響 近年癌化学療法は作用機序の異なる各種の制癌剤を 組合せる多剂併用療法が主体をなしているが，同時に 先に述べた個々の制癌剤の人睪丸に対する cytotoxic action が相乗化することも考光られ，更に放射線療法 が加つた場合に視床下部・下垂体・性腺系に与える影 響はより大さいと考兄られる。しかし文献上泌尿器科 領域の悪性腫瘍疾患について検討されたものは少な く，むしてや疾患別，対象症例の加齢を考慮したもの は見あたらない，今回の検討でも，辠丸腫瘍と腎癌，

尿路上皮腫瘍の各年齢構成が異なり，また睪丸腫瘍そ のものの内分泌学的特徵も報告されているた め12)50) 52), これらを考慮に入れ検討されなければなら ない。

自験例の睪丸腫瘍症例では，入院時又は, orchiectomy 後既に内分泌学的には FSH の高值，Tの 低值を認め, かつ精液検査, 辠丸生検でも健側睪丸の 精子形成能低下が示唆されたが，この点に関して Hamburger ${ }^{53)}$ ら, Umiker ${ }^{54)}$ seminoma 症例で尿中 FSHの上昇を報告し, 古烟5) b seminoma, nonseminoma 問わず尿中 FSH は高值を示し, orchiectomy 後もこの高值傾向が認められたと報告し, 反対側殬丸に沶いて治療前既に有意の睪丸容積の縮小 と $80 \%$ に spermatogenesis の低下をみており，この spermatogenesis の低下に対して FSH 分泌充進が起 ると述べている。また 42 名の粹丸腫瘍例の精子濃度を 検討した Thachil ${ }^{52)} ら$ む seminoma, non-seminoma にかかわらず診断時, orchiectomy 後も $2,000 \times 10^{4} /$ $\mathrm{ml}$ 以下が $52 \%$ にみらたとしている. 睪丸腫瘍の血中 Tの低值について choriocarcinoma を除いた症例で 認められたとする報告51) あるが，測定時期は制癌剤 療法あるいは放射線療法中であり治療前については測 定していない. また Lindenmeyer ${ }^{50)} ら は$ seminoma 例 で orchiectomy 前正常であつた血中 Tが術後低值を 示した事を認め, 彼らは orchiectomy 後の血中Tの低 下は, 単に unilateral semicastration のためであると 述べている.著者の経験では, 入院直後と orchiectomy
後 1〜2 週間での血中Tには変化を認めておらず，さ らに治療前血中 DHA も低值傾向を示したことを考兄 あわせると, 䁄丸腫瘍症例では治療前既に睪丸機能低 下が示唆される.

睪丸腫瘍と異なり 50 歳以降の老齢期に好発する腎 癌, 尿路上皮腫瘍については, 治療前の患者の老化に よる内分泌環境を考慮しなければならない。一般に血 中総 $\mathrm{T} は 40 － 50$ 歳代より漸減し，50～60歳になつて有 意に低下が認められ，それにつれて free $\mathrm{T}, \mathrm{T}$ の metabolic clearance rate (MCR) の低下及び Testosterone-estradiol binding globulin ( Te BG) の上昇が ある事が知られている(5) 58).

一方 LH，FSHについては，40歳代56)59)ないしは 50 ６歳代57)から上昇しはじめ LH-RH, HCG 負荷に よる反応性より, 老年者に打ける視床下部, 下垂体性 腺系の老化はまず睪丸より始まるとされてい $3^{57 / 60) 61)}$. 更には性腺に打ける動脈硬化症による血流 障害も加齢とともに進行する62)といわれていることも 考慮に入れておかなければならない。自験例における 腎癌, 尿路上皮腫瘍患者の平均年齢もそれぞれ50.7歳, 64.2歳であり, LH, FSH の上昇とTの低下を治療前に 既に認めて打り, LH-RH テスト, clomiphene テスト の結果でも分かるよらに視床下部, 下垂体予備能は正 常に保たれていることから考兵て個人差はあるもの の, 何らかの原発性幸丸機能低下が治療前既に存在し ていると考觉られた。

次に放射線療法を含む制癌剂の多剂併用療法による 殬丸機能に及ぼす影響については, Sherins ${ }^{63}$ らが若年 者特に思春期に扔ける精細管障害及び Leydig cell dysfunctionの危険性を警告している一方成人につい ては, lymphoma ${ }^{13(64) 65)}$, soft tissue sarcoma ${ }^{66)}$, testicular tumor ${ }^{52)}$ での報告があり，いずれも精細管障害 に基づく FSH の上昇を認めたとしているが, LH につ

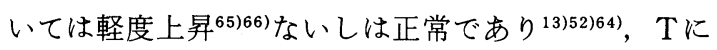
いたつては殆んど正常であり，一部症例に低下傾向を 認めたに過ぎないとしている. しかし自験例のように 対象症例の治療前内分泌動態を検討したものはなかつ た。制癌剂の多剂併用療法を行なつた尿路上皮腫瘍, 腎腫瘍に怙ける著者の検討では, 治療後 FSH（p< $0.01), \mathrm{LH}(\mathrm{p}<0.05)$ の有意の上昇を認めており, 特 に FSH に拈いて顕著であり, たた follow up を行なつ た尿路上皮腫瘍例での FSH，LH の治療前値への回復

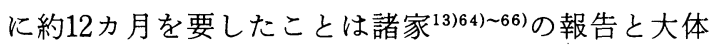
一致しており, 投与した制癌剤の種類, 期間, および 
治療前の対象症例の加齢及び個人差によりその回復速 度が左右されると考㝋る。

一旦上昇を示した FSH が正常域へと降下すること が，治療により障害された spermatogenesis の回復を 如実に物語るとするものが殆んどであるが，症例によ つてはFSH が正常復帰しているにもかかわらず aspermia であつた報告13)もあり注意を要する。

治療前後に扣ける視床下部，下垂体への影響を論じ た文献は殆んどなく比較出来ないが，自験例では clomiphene テスト，LH-RH テストでそれぞれ視床下 部予備能, 下垂体予備能を検討した結果, 少なくとも 放射線療法を含む制癌剂の多剂併用療法では視床下 部，下垂体の障害を認めなかつたことより，これらの 治療による視床下部・下垂体・性腺系への影響は，睪 丸機能低下が主体をなすと考える。また尿路上皮腫瘍, 腎癌症例に拈ける変化とは違つた意味で, 治療前既に 殬丸機能低下が存在する鋅丸腫痬症例については，放 射線療法あるいは制癌剤療法による影響が更に加重さ れたるのと推察された。

制癌剤あるいは放射線はその cytotoxic actionによ り主に精細管障害を惹起し，二次的な FSH の上昇を るたらしたと考えるが，制癌剤の多剤併用あるいは high dose の放射線で Leydig cell dysfunctionも起り らるとされて扣り ${ }^{63(66) 67)}$, FSH の增加に伴う LH の軽 度上昇の主原因として推察している報告63166) もある。

一般に, germinal cell damage及びLeydig cell damage の中枢への feed back 機構においては, FSH, LH の分泌調節因子として seminiferous tubular factor（inhibin）と血中Tがそれぞれ便宜上独立して考学 られているが，ラット睪丸に local irradiation を行な い, 睪丸の組織学的検討と血中 FSH, LH, T の変動を 観察した Hopkinson ${ }^{39}$ らは, spermatid の消失時期に 一致して FSH, LH の有意な上昇を報告し，inhibin は FSH, LH の両方に feed back 機構が働くと述べてい る. 又 $\mathrm{Main}^{68)}$ ら同様の報告をしているがその際彼 らは, feed back の強さは FSH, LH の順であつたとし ている．放射線だけでなく制癌剂投与による精細管障 害時にも血中及び下垂体中の FSH, LH の上昇を観察 した Debeljuk ${ }^{69)} ら は ， そ の$ feed back 機構にim.

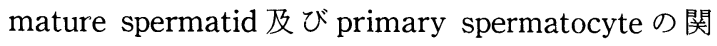
与を推察し特に前者の役割を重視した。

一方血中 T $\mathrm{T}$ LH f feed back に拈ける physiological factor であるが, 正常者にTを負荷した 場合に LH のみられずFSH も速やかに低下する事は

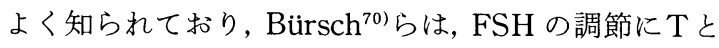
inhibin が関与して招り，Tは下垂体よりの FSH の放 出を調節し, inhibin は下垂体よりの FSH 合成を調節 しているものではないかと推論している。自験例も含 めて治療により血中丁の有意の低下を認めたものは殆 んどなく, physiological normal range内での血中 T の変動でもつてLH のみならず FSH にまで影響を及 ぼして来るとは考党難い。この点に関して $\mathrm{Bain}^{71} ら$ は, local irradiationによるラット睪丸障害の際に上 昇した FSH は inhibin によるものと考えるが，FSH にともなつて軽度上昇を認めた LH は血中 T level で は測ることの出来ない微細な Leydig cell dysfunction による feed back であろらと報告している。

いずれにしても放射線療法を含む制癌剤の多剂併用 療法による視床下部・下垂体・性腺系に打ける影響は, 原発性睪丸機能低下, 特に精細管障害であり内分泌学 的には精細管障害に基づくFSH の上昇が主体となし ている.FSH の上昇に伴い軽度上昇を認めた LH につ いては, FSH 同様精細管障害によるものかあるいは血 中Tには反映しない程度の Leydig cell damage が関 与したものかは不明であるが, 今後 Leydig cell functionの予備能力に及ぼす影響だけでなく aromatiza-

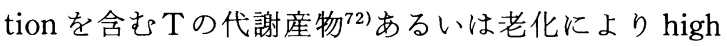

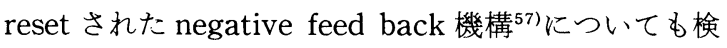
討する必要があるものと考学る。

\section{IV．副腎皮質機能に及ぼす影響}

副腎系に及ぼす放射線療法, 制癌剂療法の影響につ いて検討する際には対象症例の治療前の副腎皮質機能 を検索して扔かなければならない。一般にDHA， DHA-S, androstendione のいわゆる $\mathrm{C}_{19}$ androgens はF, aldosterone とは異なり老化とともに漸減73774)す るといわれて抢り，主として ACTH 刺激により副腎 皮質より分泌されるが，Fと異なり ACTH の feed back factor とはならない. またDHA に関しては一部 辠丸より分泌されていることが知られており, HCG 4,000iu 投与で1.4 2.5倍の血中 DHA の増加を認め $ろ^{75)}$.

DHA-S は, 血中に多量に存在し, 日内変動も少な く, 教室の大橋 ${ }^{10)}$, 森岡 ${ }^{76)}$ らは泌尿器科悪性腫瘍患者の high stage 群で低值を認めたと報告しており, 老化だ けでなく全身状態を示す 1 つの指標となり得る。著者 の検討では, 治療前 DHA-S は症例により変動が大き く, 尿路上皮腫瘍症例に低值が認められる傾向にあり, 老化による影響と共に全身状態の悪化も関与している 
ものと考皃た。 DHA が治療前正常男子群に比較し有 意な低下が認められた要因として睪丸腫瘍症例に拀い て同年代の正常男子に比し低值を示したことが考兄ら れ，治療前既に精細管障害と血中 $\mathrm{T}$ の低下が認められ たこととあわせて，健側辠丸よりの悬丸性 DHA の低 下の可能性も推察される。一方血中 Fについては正常 であり, rapid ACTH テストによる DHA, DHA-S, F の反応も正常であつたことから自験例の治療前副腎予 備能は何ら問題がないと考学る。

臨床上制癌剤による副腎皮質機能低下を検討したも のでは, Vivacqua ${ }^{77)} ら の$ Busulfan についての報告と, $\mathrm{Tobin}^{78)}$ ら6MP についての報告をみるのみである。 彼らは投与前後の Metyrapon テスト, ACTH テス 卜，血中 $\mathrm{F}$, 尿中 $17 \mathrm{OHCS}, 17 \mathrm{KS}$ の変動上り副腎皮質 機能障害は二次的であり，いずれも下垂体機能抑制が 原発であつたと述べている。

個々の制癌剤の steroidogenesis に対する影響を検

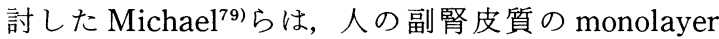
culture を用いた実験で，5Fu，5Fluorodeoxyuridine， 6MP の順に11-deoxycortisol (S), F, Corticosterone (B), deoxycorticosterone (DOC), androstendione, 11 $\beta$-hydroxy androstenedione の産生を抑制したと報 告して抢り，彼らによれば，臨床上の通常使用量と考 えられる $5 \mathrm{Fu} の$ 血中濃度である $10 \mu \mathrm{g} / \mathrm{ml}$ で steroidogenesis が80\%障害を受けたとしているが，DHA， DHA-S については検討されていない。

制癌剂自体の actionより考光てVinblastine ${ }^{80)}$, Chloramhucil ${ }^{81}$ が steroidogenesis に促進的に作用す るのではないかといわれているが，前述の Michael ${ }^{79)}$ らはこれを否定している。

自験例では放射線療法単独 3 例を含む 13 症例の治療 前後に抢けるACTH，F，DHA，DHA-S の basal level，rapid ACTH テストによる反応值を検討した が，いずれも差が認められず，少なくとも制癌剤によ り副腎皮質機能は障害をほとんど受けないと考克る。

尿路性器悪性腫瘍では, その治療前より thyroid stimulating hormone (TSH), Prolactin (PRL) が上 昇しているといら報告 ${ }^{12)}$ があり，特に non-seminoma 症例で観察されるとしている。その理由として HCG 産生により Estrogen が上昇し，二次的に PRLが上

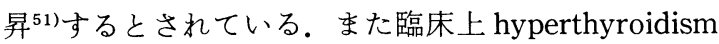
を伴わないTSHの上昇について Cochran ${ }^{82}$ らは, glycohormone である LH, FSH, HCGの 2-subunits と TSH が cross reaction したためではないかと述べ
ている.

PRL は直接副腎皮質に作用し DHA-S, DHAの分 泌促進するといら報告 ${ }^{83)}$ あるが, 著者の検討では, 治 療前 PRL は 1 例を除き正常範囲内であり，著しい高 值を示さないかぎり副腎への PRL の働きは無視出来 ると思われる。

制癌剂, 放射線療法前後に抢ける PRLの変動につ いては，治療中，治療後も有意差を認めなかつた。こ

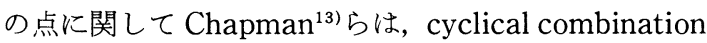
therapy を施行した74名の Hodgkin's disease 症例の $42 \%$ RRL の上昇を認めたが，TSH との間に何ら相

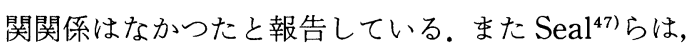
前立腺癌の放射線療法前後における PRL, T, TeBG に全く変化がみられなかつたと述べている。動物実験 に抢ける制癌剤の PRLへの影響に関しては, MTX が thyroid に働き TSH を介して二次的にPRLを上昇 ${ }^{33)}$ させたり, Vinblastine が逆に TSH の thyroidへの取 り込みを抑制する報告84) むるが，自験例では TSH を測定していないため検討は出来ないが，いずれにし ても副腎・甲状腺への制癌剂の影響を検討する場合： 個々の制癌剂そのものの直接作用なのか，それとも視 床下部・下垂体系あるいはその他の内分泌環境の変化 を介する作用であるのかを検討しなければならず今後 の検討が望まれる。

\section{結 語}

男子㲾路性器悪性腫瘍患者に対する制癌剂による多 剂併用療法及び放射線療法の視床下部・下垂体・性腺 系，副腎皮質機能に与える影響を検討するために，治 療前後の血中 LH, FSH, T を中心として, ACTH, F, DHA, DHA-S, PRL 測定し，一部症例に LH-RH テス ト， clomiphene テスト， Rapid ACTH テストを実施 した。また辠丸腫瘍患者における治療前後の精子濃度, 睪丸生検も併せ行ない検討を加え以下の結果を得た。

1）治療前に関しては，殬丸腫瘍以外の尿路上皮腫 瘍, 陰茎癌, 腎癌症例における加齡による LH, FSH の 上昇と Tの低下を認めた。

一方辠丸腫瘍例では, FSH の上昇 $(\mathrm{p}<0.001), \mathrm{T}$ の低下 $(p<0.05)$ を認め, 精子濃度, 箤丸生検でも健 側辠丸の精細管障害が示唆された。尚治療前辠丸腫瘍 症例の DHA 低值については殬丸性 DHA の低下によ るものと推察された。

2）放射線療法あるいは制癌剂療法を実施した辠丸 腫瘍例では，治療により FSH は上昇（p<0.01）を示 し，治療後 12 力月でも精子濃度と同様に治療前まで回 
復しなかつた。な拉 LH, T は治療前後で変化を認めな かつた.

3）腎癌，尿路上皮腫瘍，陰茎癌例に関しては，放射 線療法を含吉制癌剂療法後で FSH $(\mathrm{p}<0.01)$, LH $(\mathrm{p}<0.05)$ に上昇が認められ, 特に FSH に拀いて顕著 であつたが, 放射線単独療法を施行した腎癌症例では LH, FSH に全く変化を示さなかつた。 また治療により 上昇した FSH， LH は個人差があるものの，約 12 力 で治療前值に復した。

4) LH-RH テスト, clomiphene テストによる視床 下部, 下垂体予備能は, 治療前, 及び治療前後の検討 でも障害は認められず, 放射線療法を含む制癌剂療法 の視床下部・下垂体・性腺系への影響は, 個々の制癌 剂の cytotoxic action と scattered fractionated irradiationによる精細管障害を主体とする原発性辠 丸機能障害と考えられた。

5）放射線療法, 制癌剂療法に伴ら治療前後の副腎皮 質機能はほとんど障害を認めなかつた。

6) 尿路性器悪性腫瘍例の PRL は治療前, 治療後の 検討でも著変を認めなかつた.

擱筆するにあたり御校閲を賜わつた恩師，大森弘之教授 に深謝致します。また研究にあたり終始直接の御指導を頂 いた大橋輝久講師, 森岡政明博士並びに御懇切な御教示を いただきました松村陽右助教授に感謝致します。更に測定 にあたり御協力を頂いた当院中央検査部, 斎藤利興技師長, 河原厚己技官に感謝の意を表します。な打本論文の要旨は 第68回日本泌尿器科学会総会に打いて発表した。

\section{文献}

1) Harmer, M.H.: TNM-Classification of Malignant Tumors. third ed., 107-128, UICC, Geneva, 1978.

2) 吉本 純, 松村陽右, 朝日俊彦, 尾崎雄治郎, 棚橋 豊子, 金重哲三, 津島知靖, 大森弘之：泌尿器悪性 腫瘍に対するVincristine, Ifosfamide, Bleomycin 併用療法の試み(予報)。西日泌尿, 42, 761-766, 1980.

3) Holland, J.M. : Cancer of the kidney-natural history and staging. Cancer, 32, 1030-1042, 1973.

4) Krakoff, I.H., Cvitkovic, E., Currie, V., Yeh, S. and LaMonte, C.: Clinical pharmacological and therapeutic studies of bleomycin given by continuous infusion. Cancer, 40, 2027-2037, 1977.

5) Charters, J.C., Odell, W.D. and Thompson, J.C. : Anterior pituitary function during surgical stress and convalescence. Radioimmunoassay measurement of blood TSH, LH, FSH and growth hormone. J. Clin. Endocrinol. Metab., 29, 63-71, 1969.

6) 水野 茂, 堀尾 静, 舟橋啓臣, 余語 弘, 神戸川 明：血中12種ステロイドホルモンの同時測定法お よびその臨床応用。日外会誌, 81, 1476-1490, 1980.

7) Mclntosh, T.K., Lothrop, D.A., Lee, A., Jackson, B.T., Nabseth, D. and Egdahl, R.H.: Circadian rhythm of cortisol is altered in postsurgical patients. J. Clin. Endocrinol. Metab., 53, 117-122, 1981.

8）森岡政明, 大橋輝久, 赤坂輝明, 大森弘之, 高田元 敬, 新島端夫：男子性腺疾患に打情る内分泌学的 検討. 第 2 報。クロマトグラフィー不要 RIA によ る血中 Testosteroneを指標とする負荷テストの 意義. 西日泌尿, 40,491-495, 1978.

9）国分知子, 久富優子, 大内力男, 森弘, 神戸川 明, 古屋清英, 田根 培, 吉田孝雄, 高本繁夫: Dehydoroepiandrosterone 拈よび Dehydroepiandrosterone sulfate $の$ Radioimmunoassay による簡易測定法の開発. 日内分泌会誌, 54 , 117-130, 1978.

10）大橋輝久：男子に抢ける Estrogen の研究. 第 2 報。正常男子抢上び性腺疾患患者における合成 ACTH, HCG 刺激に対する血中 Estrogen 動態. 日泌尿会誌, 70, 915-927, 1979.

11）市川篤二, 熊本悦明, 広瀬欽次郎, 木下健二, 松本 恵一：辠丸の形態学的検査法. 木と臨, 11 , 129-139, 1963.

12) Dunzendorfer, U., Schumann, W., Drahovsky, D. and Ohlenschläger, G.: Glycopeptides (FSH, LH, TSH, Prolactin) and Glycoproteins in patients with genitourinary cancer. Oncology, 38, 110-115, 1981.

13) Chapman, R.M., Sutcliffe, S.B., Rees, L.H., Edwards, C.R.W. and Malpas, J.S.: Cyclical combination chemotherapy and gonadal function. Lancet, 1, 285-289, 1979.

14) Vilar, O.: Effect of cytostatic drugs on human testicular function, Male Fertility and Sterility. edited by Mancini, R.E. and Martini, L., 423 -440, Academic Press Inc. LTD., London, 1974.

15) Landing, B.H., Goldin, A. and Hoe, H.A.: Testicular lesion in mice following parenteral administration of Nitrogen-mustards. Cancer, 2, 1075-1082, 1949.

16) Gerlinger, P. et Clavert, J.: Action du cyclophosphamide injecté à différentes périodes de la gestion sur les cellules sexuelles embryonna ires de Lapin. Comp. Rend. Sci. Soc. Biol., 158, 2464-2466, 1964. 
17）山内卯三郎：制癌剂によるマウス辠丸障害と回復 に関する実験的研究. 鹿児島大学医学雑誌, 18 , 783-820, 1967.

18) Fairley, K.F., Barrie, J.U. and Johnson, W.: Sterility and testicular atrophy related to cyclophosphamide therapy. Lancet, 1, 568-569, 1972.

19) Kumar, R., Biggart, J.D., McEvoy, J. and McGeown, M.G.: Cyclophosphamide and reproductive function. Lancet, 1, 1212-1214, 1972.

20) Rapola, J., Koskimies, O., Huttunen, N.P., Floman, P., Vilska, J. and Hallman, N.: Cyclophosphamide and the pubertal testis. Lancet, 1, 98-99, 1973.

21) Kirkland, R.T., Bongiovanni, A.F., Cornfeld, D., McCormick, J.B., Parks, J.S. and Tenore, A.: Gonadotropin responses to luteinizing releasing factor in boys treated with cyclophosphamide for nephrotic syndrome. J. Pediatr., 89, 941-944, 1976.

22) Galton, D.A.G., Till, M. and Wiltshaw, W.: Busulfan: Summary of clinical results. Am. N. Y. Acad. Sci., 68, 967-973, 1957.

23) Spitz, S.: The histological effects of nitrogen mustards on human tumors and tissues. Cancer, 1, 383-398, 1948.

24）大井好忠：制癌剂膀脂内注入療法の抗腫瘍効果. 西日泌尿，38，233-235， 1976.

25) Richter, P., Calamera, J.C., Morgenfeld, M.C., Kiersgznbaum, A.L., Lanieri, J.C. and Mancini, R.E. : Effect of chlorambucil on spermatogenesis in the human with malignant lymphoma. Cancer, 25, 1026-1030, 1970.

26) Guesry, P., Leneir, G. and Broyer, M. : Gonadal effects of chlorambcil given to prepubertal and pubertal boys for nephrotic syndrome. J. Pediatr., 92, 299-303, 1978.

27) Smith, R.H. and Barrett, O.: Gynecomastia associated with vincristine therapy. Calfornia Medicine, 107, 347-349, 1967.

28）伊藤尚一：各種抗腫煌物質のマウス精巣に対する 影響. 日不妊会誌，4，187-194，1959.

29) Lee, I.P. and Dixon, R.L.: Antineoplastic drugs effects on spermatogenesis studies by velocity sedimentation cell separation. Toxicol. Appl. Pharmacol., 23, 20-41, 1972.

30) Lu, C.C. and Meistrich, M.L.: Cytotoxic effects of chemotherapeutic drugs on mouse testis cells. Cancer Res., 39, 3575-3582, 1979.

31) Frank, L., Lichtman, H. and Petron, P.: Experiences with methotrexate in psoriasis. Dermatologica, 137, 87-96, 1968.
32) EL-Beheiry, A., EL-Mansy, E., Kamel, N. and Salama, N.: Methotrexate and fertility in men. Archives of Andrology, 3, 177-179, 1979.

33) Kuo, E.Y.H., Esher, H.T., Tayler, D.J. and Bogden, A.E.: Effect of cancer chemotherapeutic agents on endocrine organs and serum levels of estrogens, progesterone, prolactin and luteinizing hormone. Cancer Res., 35, 1975-1980, 1975.

34) Bertazzoli, C., Chieli, T., Ferni, G., Ricevuti, G. and Solcia, E.: Chronic toxicity of adriamycin: A new antineoplastic antibiotic. Toxicol. Appl. Pharmacol., 21, 287-301, 1972.

35) Anderson, K.J. and Bajpai, P.K.: Effect of adriamycin on testes and seminal vesicles adult male rats. IRCS Medical Science : Cancer; Cell and Membrane Biology ; Drug Metabolism and Toxicology; Endocrine System; Kidneys and Urinary System; Pathology ; Pharmacology ; Physiology; Reproduction, Obstetrics and Gynecology; Social and Occupational Medicine, 8, 250-251, 1980.

36) Devita, V.T., Canellos, G.P. and Moxley, T.H. : A decade of combination chemotherapy for advanced Hodgkin's disease. Cancer, 30, 1495-1505, 1972.

37) Schaeppi, U., Heyman, I.A., Fleischman, R.W., Rosenkrantz, H., Ilievski, V., Phelan, R., Cooney, D.A. and Davis, R.D., Tox. Appl. Parmacol., 25, 230-241, 1973.

38) Abe, H.H.: Toxicological investigation of Ifosfamide, Proceeding International Holoxan Symmposium 21-23, 3, 1977, Dürsseldorf, 46 -49, ASTA-WERKE AG. Bielefeld, 1977.

39) Hopkinson, C.R.N., Dulisch, B., Gauss, G., Hilscher, W. and Hirschäuser, C.: The effect on local testicular irradiation on testitular histology and plasma hormone levels in the male rat. Acta Endocr., 87, 413-423, 1978.

40) Rowley, M.T., Leach, D.R., Warner, G.A. and Heller, C.G. : Effects of graded doses of ionizing radiation on the human testis. Radiat. Res., 59, 665-678, 1974.

41) Smithers, D.W. and Wallace, E.N.: Radiatherapy in the treatment of patients with seminoma and tetatoma of the testicle. Br. J. Urol., 34, 422-235, 1962.

42) Speiser, B., Rubin, P. and Casarett, G.: Aspermia following lower truncal irradiation in Hodgkin's disease. Cancer, 32, 692-698, 1973.

43) Van der Werf-Messing, B.: Radiotherapeutic treatment of testicular tumors. Int. J. Radiat. 
Oncol. Biol. Phys., 1, 235-248, 1976.

44) Hahn, E.W., Stephen, M., Feingold, B.S. and Nisce, L.: Aspermia and recovery of spermatogenesis in cancer patients following incidental gonadal irradiation during treatment. A progress report. Radiology, 119, 223-225, 1976.

45) Moss, W.T., Brand, W.N. and Battifora, H. : The testicle, Radiation oncology. Rationale, Technique, Results, 5th ed., 417-439, The C.V. Mosby Company, London, 1979.

46) Ash, P.: The influence of radiation on fertility in man. Brit. J. Radiol., 53, 271-278, 1980.

47) Seal, U.S. and The Veterans Administration Uro-Oncology Research Group: FSH and LH elevation after radiation for treatment of cancer of the prostate. Invest. Urol., 16, 278-280, 1979.

48) Sandeman, J.F.: The effects of X-irradiation on male human fertility. Brt. J.Radiol., 39, 901-907, 1966.

49) Antoku, S. and Russell, W.J.: Dose to the active bone marrow, gonads and skin from roentgenography and fluoroscopy. Radiology, 101, 669-678, 1971.

50) Lindenmeyer, D., Hornung, D. and Körner, F. : Hormonal changes in urine and plasma in patients with various testicular tumors before and after treatment. I. Seminoma. Urol. Int., 28, 135-144, 1973.

51) Stepanas, A.V., Samaan, N.A., Schultz, P.N. and Holoye, P.Y.: Endocrine studies in testicular tumor patients with and without gynecomastia. A report of 45 cases. Cancer, 41, 369-376, 1978.

52) Thachil, J.V., Jewett, M.A.S. and Rider, W.D. : The effects of cancer and cancer therapy on male fertility. J. Urol., 126, 141-145, 1981.

53) Hamburger, C. and Goldfredsen, E.: Studies on gonadotropic hormones in cases of testicular tumors. Acta Path. Microbiol. Scand., 13, 75-102, 1936.

54) Umiker, W.: Interstitial cell hyperplasia in association with testicular tumors: A study of its relationship to urinary gonadotropins, testicular atrophy and histological type of tumor. J. Urol., 72, 895-903, 1954.

55）古畑哲彦：睪丸腫瘍患者の殬丸機能に関する研 究. 日泌尿会誌, 64, 1009-1026, 1973.

56) Baker, H.W.G., Burger, H.G., DeKretser, D.M., Hudson, B., O'Conner, S., Wang, C., Mirovics, A., Court, J., Dunlop, M. and Rennie, G.C. :
Changes in the pituitary-testicular system with age. Clin. Endocrinol., 5, 349-372, 1976.

57）加藤堅一, 本松利治, 赤嶺康夫, 名和田新, 植田太 郎, 合馬 紘, 梅田文夫, 土師正文, 牟田和夫：シ ンポジゥムI：老化とホルモン 2 .下垂体性腺系 (男子). 日内泌会誌，53，1300-1309， 1977.

58) Vermeulen, A., Rubens, R. and Verdonck, L. : Testosterone secretion and metabolism in male senescence. J. Clin. Endocr., 34, 730-735, 1972.

59) Stearns, E.L., MacDonnell, J.A., Kafman, B.J., Padua, R., Lucman, T.S., Winter, J.S.D. and Faiman, C. : Declining testicular function with age. Hormonal and clinical correlates. Amer. J. Med., 57, 761-766, 1974.

60) Rubens, R., Dhont, M. and Vermeulen, A. : Further studies on Leydig cell function in old age. J. Clin. Endocrinol. Metab., 39, 40-45, 1973.

61）江夏朝松, 能本悦明：睪丸内分泌機能の指標とし ての血中Testosterone, Estradiol および Estradiol/Testosterone 比の検討. 悬丸機能の研 究. 第 9 報. 日泌尿会誌, 72, 1450-1469, 1981.

62) Sassano, N. and Ichijo, S. : Vascular patterns of human testis with special reference to its senile changes. Tohoku J. Exp. Med., 99, 269-280, 1969.

63) Sherins, R.J., Olweny, C.L.M. and Ziegler, J.L. : Gynecomastia and gonadal dysfunction in adolescent boys treated with combination chemotherapy for Hodgkin's disease. N. Engl. J. Med., 299, 12-16, 1978.

64) Sherins, R.J. and Devita, V.T.: Effect of drug treatment for lymphoma on male reproductive capacity. Studies of men in remission after therapy. Ann. Int. Med., 79, 216-220, 1973.

65) Roeser, H.P., Stocks, A.E. and Smith, A.J.: Testicular damage due to cytotoxic drugs and recovery after cessation of therapy. Aust. N. Z. J. Med., 8, 250-254, 1978.

66) Shamberger, R.C., Sherins, R.J. and Rosenberg, S.A.: The effects of postoperative adjuvant chemotherapy and radiotherapy on testicular function in men undergoing treatment for soft tissue sarcoma. Cancer, 47, 2368-2374, 1981.

67) Rich, K.A., Kerr, J.B. and De Kretser, D.M. : Evidence for leydig cell dysfunction in rats with experimentally induced seminiferous tubule camage. Molecular and Cellular Endocrinology, 13, 125-135, 1979.

68) Main, S.J., Davies, R.V., Young, M.G.W.L. and Setchell, B.P.: Serum and pipuitary gonadotrophins after destruction of germinal 
cells in the testis by X-irradiation or heat. J. Endocr., 69, 23p, 1976.

69) Debeljuk, L., Arimura, A. and Schally, A.V.: Pituitary and serum FSH and $\mathrm{LH}$ levels after massive and selective depletion of the germinal epithelium in the rat testis. Endocrinology, 92, 48-54, 1973.

70) Bürsch, G., Mauss, J., Richter, E., Bormacher, K. Leyendecker, G. and Nocke, W.: The role of testosterone in the feedback control of male FSH and LH secretion. Klin. Wschr., 53, 237-239, 1975.

71) Bain, J. and Keene, J.: Further evidence for inhibin: Change in serum luteinizing hormone and follicle-stimulating hormone levels after Xirradiation of rat testes. J. Endocr., 66, 279-280, 1975 .

72）野口和美：雄ラットに括ける Gonadotropin の中 枢性調節に関する研究. 第 1 報一Testosterone 代 謝産物脳内投与の，血中 Gonadotropin 值沉与兄 る影響. 日内分泌会誌，57，1139-1147，1981.

73）井林 博, 加藤堅一, 本松利治, 名和田新, 稙田太 郎, 赤嶺康夫, 合場 紘 : 老化とホルモン. 日本老 年医学会雑誌, 11, 138-146, 1974.

74) Zumoff, B., Rosenfeld, R.S., Strain, G.W., Levin, J. and Fukushima, D.K. : Sex differences in the twenty-four-hour mean plasma concentrations of dehydroepiandrosterone (DHA) and dehydroepiandrosterone sulfate (DHAS) and the DHA to DHAS ratio in normal adults. J. Clin. Endocrinol. Metab., 51, 330-333, 1980.

75) Nieshlag, E., Loriaux, D.L., Ruder, H.J., Zucker, I.R., Kirschner, M.A. and Lipsett, M.B. : The secretion of dehydroepiandrosterone and dehydroepiandrosterone sulfate in man. J. Endocr., 57, 123-134, 1973 .
76）森岡政明：前立腺癌の内分泌学的研究. 第 1 報. 前 立腺癌患者に打ける血中内分泌動態. 日泌尿会誌, 72, 953-966, 1981.

77) Vivacqua, R.J., Haurani, F.I. and Erslev, A.J. : "Selective pituitary insufficiency secondary to Busulfan. Ann. Intern. Med., 67, 380-387, 1967.

78) Tobin, M.S., Kyung, S.K. and Kossowsky, W. A. : Adrenocorticotrophic-hormone deficiency in chronic myelogenous leukemia after treatment. N. Engl. J. Med., 282, 187-190, 1970.

79) Michael, W.E.M. and Michael, J.O.: Cytotoxic drugs and the human adrenal cortex. A cell culture study. Cancer, 43, 969-979, 1979.

80) Temple, R. and Woolf, J.: Stimulation of steroid secretion by antimicrotubular agents. J. Biol. Chem., 248, 2691-2698, 1973.

81) Tisdale, M.J. and Phillips, B.J. : Inhibition of cyclic $3^{\prime}, 5^{\prime}$-nucleotide phosphodiesterase-A possible mechanism of action of bifunctional alkylating agents. Biochem. Pharmacol., 24, 211-217, 1975.

82) Cochran, J.S., Walsh, P.C., Porter, J.C., Nicholson, T.C., Madden, J.D. and Peters, P.C.: The endocrinology of human chorionic gonadotropin-secreting testicular tumors: new methods in diagnosis. J. Urol., 114, 549-555, 1975.

83) Vermeulen, A., Suy, E. and Rubens, R. : Effect of prolactin on plasma DHEA(S) levels. J. Clin. Endocrinol. Metab., 44, 1222-1225, 1977.

84) Ekholm, R., Ericson, L.E., Josefsson, J.O. and Melander, A. : In vivo action of vinblastine on thyroid ultrastructure and hormone secretion. Endocrinol., 94, 641-649, 1974.

(1982年 9 月 2 日受付) 